\title{
Pilot Study of Behavioral Activation as Adjunct Treatment for Depression in Primary Care
}

\author{
Lindsay Ellen Toler \\ West Virginia University, Itoler@mix.wvu.edu
}

Follow this and additional works at: https://researchrepository.wvu.edu/etd

Part of the Behavioral Medicine Commons, Community Health Commons, and the Primary Care Commons

\section{Recommended Citation}

Toler, Lindsay Ellen, "Pilot Study of Behavioral Activation as Adjunct Treatment for Depression in Primary Care" (2020). Graduate Theses, Dissertations, and Problem Reports. 7866.

https://researchrepository.wvu.edu/etd/7866

This Problem/Project Report is protected by copyright and/or related rights. It has been brought to you by the The Research Repository @ WVU with permission from the rights-holder(s). You are free to use this Problem/Project Report in any way that is permitted by the copyright and related rights legislation that applies to your use. For other uses you must obtain permission from the rights-holder(s) directly, unless additional rights are indicated by a Creative Commons license in the record and/ or on the work itself. This Problem/Project Report has been accepted for inclusion in WVU Graduate Theses, Dissertations, and Problem Reports collection by an authorized administrator of The Research Repository @ WVU. For more information, please contact researchrepository@mail.wvu.edu. 
Pilot Study of Behavioral Activation as Adjunct Treatment for Depression in Primary Care

Lindsay E. Toler

\author{
Project Report submitted \\ to the School of Nursing \\ at West Virginia University
}

in partial fulfillment of the requirements for the degree of

Doctor of Nursing Practice in

Nursing

\author{
Kendra L. Barker, DNP, APRN, FNP-BC \\ Amy L. Ankrom, MSN, APRN, PMHNP-BC \\ Department of Family/Community Health
}

Morgantown, West Virginia

2020

Keywords: behavioral activation, depression, primary care

Copyright 2020 Lindsay E. Toler 


\begin{abstract}
Pilot Study of Behavioral Activation as Adjunct Treatment for Depression in Primary Care

Lindsay E. Toler
\end{abstract}

Many individuals receiving care at a predominantly free primary health care clinic in the northern part of West Virginia are experiencing depression, and medication therapy is the most common form of management with limited resources for psychosocial treatment. Brief psychosocial therapy interventions provided by the primary care provider should be explored as an adjunct treatment for this population in the primary care setting.

A pilot study was conducted to explore the integration of behavioral activation, a brief psychosocial intervention focused on decreasing depressed behavior by increasing nondepressed behavior to reinforce corresponding improvements in mood. Eligible patients were invited to attend five sessions once for five weeks. Visits were conducted according to the revised manual for Behavioral Activation Treatment for Depression. Data collection included measurements for adherence to treatment, PHQ-9, and BADS scores.

Three primary aims were evaluated for this project: 1) To assess the feasibility of implementing this intervention in this clinic population; 2) To decrease overall PHQ-9 scores and increase overall BADS scores; and 3) To increase medication adherence in conjunction with a psychosocial intervention.

The feasibility evaluation of this project was performed according to Bowen's feasibility criteria and showed mixed results. Data suggests there was no statistically significant difference in depressive symptoms or daily functioning but minor improvements were noted, indicating potential clinical significance. Limitations of this study included low patient enrollment and the COVID-19 pandemic. Future research could include implementation of this intervention in an integrated care center, larger clinic, or with a different clinic population. 


\section{Acknowledgements}

I would first like to dedicate this manuscript to my grandmother, Lois S. Casto, a truly kindred spirit in the pursuit of knowledge and education.

I would like to thank those family members who walked this journey with me, providing the support and encouragement needed to complete this project. Heartfelt and sincere thanks go to my mother, Mary, my father, Nelson, my brother, Vince, and my sister-in-law, Emily, for boosting me up during difficult times and standing by my side every step of the way. Without the love and support of my family, none of this would have been possible.

I would also like to thank my faculty of record, Kendra Barker, for her guidance, inspiration, and strength which enabled me to persevere and finish this project successfully. I would like to thank my committee member, Amy Ankrom, for providing expertise and insight on this population and supporting me during this project. 


\section{Table of Contents}

$\begin{array}{ll}\text { Acknowledgements } & \text { iii }\end{array}$

Table of Contents $\quad$ iv

Introduction 1

$\begin{array}{ll}\text { Background } & 1\end{array}$

Significance of Project 1

Problem Statement 4

Purpose of Project 4

$\begin{array}{ll}\text { Literature Review } & 5\end{array}$

$\begin{array}{ll}\text { Literature Synthesis } & 15\end{array}$

$\begin{array}{ll}\text { Theoretical Framework } & 15\end{array}$

$\begin{array}{ll}\text { Project } & 17\end{array}$

$\begin{array}{ll}\text { Intervention Plan } & 17\end{array}$

$\begin{array}{ll}\text { Feasibility Analysis } & 20\end{array}$

Evidence of Site Support 22

$\begin{array}{ll}\text { Timeline } & 22\end{array}$

Measurable Project Objectives 22

$\begin{array}{ll}\text { Data Analysis } & 24\end{array}$ 
$\begin{array}{ll}\text { Results } & 24\end{array}$

$\begin{array}{ll}\text { Participation Summary } & 24\end{array}$

$\begin{array}{ll}\text { Treatment Summary } & 25\end{array}$

$\begin{array}{ll}\text { Demographic Data Summary } & 26\end{array}$

$\begin{array}{ll}\text { Evaluation Results } & 26\end{array}$

Discussion and Recommendations 29

$\begin{array}{ll}\text { DNP Essentials } & 33\end{array}$

$\begin{array}{ll}\text { References } & 36\end{array}$

$\begin{array}{ll}\text { Appendix A } & 43\end{array}$

$\begin{array}{ll}\text { Appendix B } & 61\end{array}$

$\begin{array}{lr}\text { Appendix C } & 62\end{array}$

$\begin{array}{ll}\text { Appendix D } & 63\end{array}$

$\begin{array}{ll}\text { Appendix E } & 64\end{array}$

$\begin{array}{ll}\text { Appendix F } & 65\end{array}$

$\begin{array}{ll}\text { Appendix G } & 65\end{array}$

$\begin{array}{ll}\text { Appendix } \mathrm{H} & 66\end{array}$ 


\section{Introduction}

Depression is a prevalent illness in West Virginia (WV DHHR, 2018). Many individuals receiving care at a predominantly free primary health care clinic in the northern part of the state are experiencing depression, and medication therapy is the most common form of management as there are limited resources for treatment like psychiatry or formal counseling. Despite medication management, a noticeable amount of depression screenings for ongoing monitoring show moderate to severe depression scores without improvement. Psychosocial therapy delivered by primary care providers should be explored as an adjunct treatment for this population in primary care settings. Current practice must be modified to improve depressive illnesses and their sequela in this population as patients with untreated depression suffer from greater comorbidities and earlier mortality than their non-depressed counterparts (Coryell, 2018).

\section{Background}

A diagnosis of major depressive disorder (MDD) requires the presence of five or more symptoms over a two-week period that include either depressed mood or anhedonia (American Psychiatric Association [APA], 2013). People with major depression may experience a lack of interest or pleasure in daily activities, significant weight loss or gain, insomnia or excessive sleeping, lack of energy, inability to concentrate, feelings of worthlessness or excessive guilt, and recurrent thoughts of death or suicide (American Psychological Association, 2020).

According to the Center for Disease Control (CDC, 2015) between the years 2013 and 2016, $8.1 \%$ of Americans aged 20 and older were diagnosed with depression.

\section{Significance of Project}


The lifetime prevalence of major depression in the United States is 17\% (Krishnan, 2019). The prevalence of depression in West Virginia is significantly higher at 23.8\% (WV DHHR, 2018). Depression is associated with coronary heart disease (CHD), diabetes mellitus (DM), Parkinson's disease (PD), stroke CVA), and dementia (Coryell, 2018). These associations could be due to the disease process itself or impaired functioning related to the disease (Krishnan, 2019). Depression is also associated with earlier mortality. People with serious mental illnesses die about 25 years earlier than the general population (Mauer, 2006). Studies show that the likelihood of mortality due to any cause is about 50 to $100 \%$ greater in depressed individuals, compared with nondepressed individuals (Coryell, 2018). Death due to suicide, homicide, and accidental death is also increased in patients with depression (Coryell, 2018). The most recent data from the CDC for West Virginia shows a steady increase in deaths associated with suicide, homicide, firearms, and overdoses during the years 2014 to 2017 (CDC, 2018). These statistics indicate a significant need for increased access to treatment for depression in West Virginia.

Center for Disease Control statistics demonstrate a correlation between depression and socioeconomic status. This data shows that $15.8 \%$ of adults from families living below the federal poverty level have depression, but the prevalence of depression decreases as family income levels increase (Brody, Pratt, \& Hughes, 2018). In West Virginia, depression is significantly higher among people with less than a high school education and an annual household income of less than $\$ 15,000$ (WV DHHR, 2018). In a sample of patients with a lower socioeconomic status at a free, rural, primary care clinic in West Virginia, 39\% of patients had a diagnosis of depression (McCrone et al., 2007). Factors predictive of depression were younger age, lower education level, alcohol use, and unemployment (McCrone et al., 2007). Services for medication and psychiatry referral exist in the clinic of interest (L. Jones, personal 
communication, December 15, 2019); however, low availability of resources such as funding and transportation make the likelihood of success for outpatient psychiatry referrals unreliable. Moreover, West Virginia is not prepared to meet the need for specialty treatment of mental illness. The state ranks 49th in mental health workforce availability with one provider for every 890 patients (Hellebuyck, Halpern, Nguyen, \& Fritze, 2019). According to the CDC, 10.4\% of all primary care visits were used to address depressive symptoms (2015). They also note that between the years 2011 and 2014, 12.7\% of people aged 12 and older used antidepressant medication (Pratt, Brody, \& Gu, 2017). Amidst the current treatment options in primary care, the rate and severity of depression appear to be increasing (WV DHHR, 2018).

Due to this shortage of mental health providers, psychosocial treatments for depression should be considered for integration into primary care services. Treatments must be timely and providers must be easily trained to enhance feasibility and engagement. While cognitivebehavioral therapy is the gold standard for depression, it requires a significant time commitment and must be implemented by providers with specialty training. Behavioral therapy is not a novel treatment, but interest in its usefulness and simplicity has been recently renewed. The behavioral approach was pioneered by Ferster (1973) and Lewinsohn (1974), both of whom recognized a link between avoidant behavior and depression. They recommended the use of behavioral activation strategies to increase positive reinforcement with the environment and subsequently improve mood (Ferster, 1973 \& Lewinsohn, 1974). There are two current evidence-based methods for behavioral activation strategies: Behavioral Activation and the Brief Behavioral Activation Treatment for Depression (Turner \& Leach, 2012). Behavioral activation strategies emphasize the importance of reinforcement as a means of treatment (Turner \& Leach, 2012). Recent approaches to behavioral activation focus on decreasing depressed behavior by increasing 
nondepressed behavior to reinforce the corresponding improvements in mood that these actions produce (Turner \& Leach, 2012). During treatment with behavioral activation, the provider works with the patient to identify patterns of reinforcing behavior and the contingencies between those behaviors and their consequences (Turner \& Leach, 2012). With activation techniques, an automatic consequence of increasing positively reinforcing behaviors results in the decrease of negatively reinforcing behaviors that perpetuate depressive symptoms (Turner \& Leach, 2012). Behavioral activation itself involves collaboration between provider and patient to identify behaviors that elicit and reinforce depressive symptoms, and then choosing positive behaviors for activation (Turner \& Leach, 2012). Due to its simple, straightforward technique and implementation without complex training, behavioral activation has the potential to be a valuable treatment for depression in primary care.

\section{Problem Statement}

Patients with a lower socioeconomic status tend to have an increased rate of depression (Brody, Pratt, \& Hughes, 2018; WV DHHR, 2018). At a rural, predominantly free, primary care clinic in northern West Virginia, a large percentage of patients with these characteristics are diagnosed with depression (McCrone et al., 2007). Screening during treatment often reflects little to no improvement in depression scores (C. Wang, personal communication, December 15, 2019). Due to a lack of resources, referral to higher levels of specialty care is often impractical. Changes in clinician practice are being explored to address persistent depressive symptoms.

\section{Purpose of Project}

This pilot study implemented the Brief Behavioral Activation Treatment for Depression in consenting patients with depression. This intervention has been shown to decrease severity of 
symptoms and improve patient behaviors associated with depression. Implementing behavioral activation as part of depression treatment in a low socioeconomic status population at a primary care clinic had the potential to improve depression outcomes.

\section{Literature Review}

An advanced literature search was conducted on December 14, 2019 using EbscoHost. Most notable databases included were Cochrane Library, CINAHL, Medline PubMed, and PsycINFO. Searches included various combinations of key words "behavioral activation," "Behavioral Activation for Treatment of Depression," "primary care," "primary care clinic," and “depression.” Inclusion criteria were human subjects, English language, and publication between 2000 and 2019. Exclusion criteria included studies on forms of depression other than major depressive disorder, depression associated with other illnesses, and studies with an adolescent and/or child population. After duplicates were removed and inclusion and exclusion criteria were applied, nine articles were found suitable for review (see Appendix A for evidence table with more complete study details).

The first article chosen for review was a randomized control trial by Dimidjian et al. (2006) comparing behavioral activation, cognitive therapy, anti-depressant medication (ADM), and placebo control (PLA). The purpose of this study was to assess the effectiveness of behavioral activation (BA) as a treatment for major depression compared to cognitive therapy (CT) and ADM in the presence of a placebo control. Participants were randomly assigned to a treatment group using a computer-generated randomization list. Treatment groups consisted of BA, CT, ADM, or PLA. Severity of depression was used as a stratification of randomization. There was significant overall improvement across all conditions in the high-severity subgroup on the BDI $(p<0.0001)$ and the HRSD $(p<0.0001)$. Participants in the BA condition improved 
significantly more per week than participants in the CT condition on the BDI $(p=0.029)$ and the HRSD $(p=0.03)$. Patients in the ADM condition also improved significantly more per week than participants in the CT condition on the BDI $(p=0.007)$ and the HRSD $(p=0.022)$. No significant differences were found comparing participants in the BA and ADM conditions on BDI or HRSD. There were significant overall improvements across all conditions in the lowseverity subgroup on the BDI $(p<0.0001)$ and the HRSD $(p<0.0001)$, but there was no evidence of differences in improvement between treatments on the BDI or HRSD. For rates of response in the high-severity subgroup, data showed that significantly more participants in the BA condition met response criteria compared to those receiving CT $(p=0.048)$ or ADM $(p=$ 0.027). For rates of remission in the high-severity subgroup, data showed significant differences between treatments on the HRSD $(p=0.012)$ and a significantly greater percentage of remission for participants in the $\mathrm{BA}$ condition compared with participants in the $\mathrm{ADM}$ condition $(p=$ 0.002). From these findings, authors concluded that BA is similarly efficacious to ADM and more effective than CT. In more severely depressed patients, BA treatment resulted in a significantly larger number of participants reaching remission, and keeping a higher percentage of patients in treatment. These results highlight the importance of simple behavioral strategies in the treatment of depression.

The next article for review is a meta-analysis conducted by Cuijpers, van Straten, and Warmerdam (2007). The purpose of this meta-analysis was to examine the effects of activity scheduling (AS) on depression, the effects of activity scheduling compared to other treatments, and the long-term effects of activity scheduling. The literature included 16 studies with a total of 780 participants for this meta-analysis. Results showed that the mean effect size between activity scheduling and control condition was large, favoring activity scheduling. The pooled 
effect size between activity scheduling and other psychological treatments was small, favoring activity scheduling but without a significant difference. The pooled effect size between activity scheduling and cognitive therapy was small, favoring activity scheduling. The pooled effect size between activity scheduling and a combination of CT and AS was small, favoring the combination of CT and AS. The pooled effect size between CT and a combination of CT and AS was small, favoring the combination of CT and AS. The effect size between activity scheduling and antidepressant medication was small, favoring activity scheduling. The effects of activity scheduling compared to a control condition at follow-up was large at two months and moderate at six months, suggesting some corroboration for the effectiveness of activity scheduling at longterm follow-up. The effect size between activity scheduling and CT at 1-2 months and 4-6 months was small, indicating nonsignificant differences between CT and activity scheduling at follow-up. From this data, authors concluded that activity scheduling is effective in the treatment of depression in adults. The overall effect size of activity scheduling is large, and similar to effect sizes found for other psychological treatments and antidepressants.

The next article for review is a meta-analysis by Ekers, Richards, and Gilbody (2007). The purpose of this study was to compare the effectiveness of behavioral therapy (BT) interventions to other psychosocial treatments and control conditions. Twenty studies were included with a total of 1,109 participants. Interventions in these studies included BT, treatment as usual (TAU) or control condition, CBT/CT, brief psychotherapy, or supportive counseling. Results for studies comparing BT and control conditions showed a significant difference between symptom level scores favoring BT over control $(p<0.001)$. There were also significantly larger rates of recovery in BT conditions than control $(p=0.03)$. Results for studies comparing BT and CBT/CT showed no difference in depression levels at post-treatment $(p=0.46)$. Results for 
studies comparing BT and brief psychotherapy showed a significant difference between symptom level scores favoring BT over psychotherapy $(p=0.01)$. There were significantly higher rates of recovery observed in the BT condition than psychotherapy $(p=0.01)$. Results for studies comparing BT and supportive therapy showed a significant difference between conditions favoring $\mathrm{BT}(p=0.02)$. From these results, authors conclude that $\mathrm{BT}$ is an effective treatment for depression and is superior to control conditions, supportive counseling, and brief psychotherapy. Authors also concluded that BT and CBT resulted in equivalent results with no statistically significant differences in post-treatment and follow-up symptom levels, recovery rates, or drop outs. These findings indicate that BT is as effective and acceptable as CBT/CT. The authors mention that data from this study did not support the assumption that BT may afford shorter training of less-qualified individuals to relieve the burden on therapist availiabity and demand; however, a meta-regression examining the impact of level of training for delivery of BT did not find that superior outcomes were associated with higher level of qualifications. Overall, authors conclude that $\mathrm{BT}$ is an effective treatment for depression with equal, or better, outcomes than treatments currently recommended.

The next article for review by Dobson et al. (2008) is a randomized control trial that builds on the findings of the RCT by Dimidjian et al. published in 2006. The purpose of this study is to determine the sustained effectiveness of prior $\mathrm{CT}, \mathrm{BA}$, or continued ADM in the presence of a placebo control, and whether the effects of CT or BA extended into the second year of follow-up. This study measured the rates of relapse or recurrence of depression in the participants of the Dimidjian et al. study. Assessments were conducted biweekly for the first two months of the first-year follow-up phase, and then at three, six, 12, 13, 14, 18, and 24 months. Data showed that relapse was highly likely at the beginning of the first follow-up year, especially for those 
withdrawn onto placebo. Rates of relapse during the first follow-up year showed that active treatments $(\mathrm{CT}, \mathrm{BA}$, or $\mathrm{ADM})$ resulted in significantly lower rates of relapse than withdrawal to placebo $(p=0.04)$. Taken individually, prior CT was significantly better than withdrawal to placebo $(p=0.02)$ and prior BA resulted in lower rates of relapse at a nonsignificant level $(p=$ 0.09). Rates of relapse were not significantly different between continued ADM and withdrawal to placebo $(p=0.33)$. Prior exposure to CT reduced the risk for relapse by $64 \%$ compared to medication withdrawal, while continued ADM reduced the risk for relapse by about 33\%, and prior exposure to BA reduced the risk for relapse by 51\%. Participants in the continued ADM condition were withdrawn to placebo at the beginning of the second-year of follow-up. Rates of recurrence during the second-year of follow-up were lower in the prior CT and BA conditions than prior continued ADM but not with a significant trend $(p=0.06)$. Overall, prior CT and BA were significantly superior to continuation of $\operatorname{ADM}(p=0.04)$ and medication withdrawal. Prior exposure to CT was significantly superior to continued $\operatorname{ADM}(p=0.02)$ and prior exposure to BA showed a nonsignificant trend in the same direction $(p=0.08)$. From these results, authors concluded that prior exposure to either $\mathrm{CT}$ or BA resulted in an ongoing effect that was at least as effective as continued medication treatment, including the prevention of relapse and possibly recurrence.

The next article for review is a randomized control trial by Gawrysiak, Nicholas, and Hopko (2009). The purpose of this study was to assess the effectiveness of a single-session BA intervention based on the BATD protocol. Participants were recruited online from an introductory psychology course at a Southeastern university. Eligible participants who agreed to take part in the study were randomly assigned to the treatment or control group. The intervention protocol was adapted from the BATD treatment manual by Lejuez, Hopko, and Hopko in 2001. 
The treatment was reduced from a nine-session protocol to one session, which resulted in decreased activity scheduling and exclusion of behavioral contracting strategies. Outcome measures were assessed using the BDI, to measure depression symptom severity, the EROS, to measure environmental reward and response-contingent positive reinforcement (RCPR) with higher scores suggesting increased environmental reward, the BAI, to measure symptoms of anxiety, and the MSPSS, to measure the social support from participants' family and friends, with higher scores indicating decreased social support. The authors also measured adherence to treatment using the weekly behavioral checkout sheets that participants returned to clinicians at the follow-up visit. Analysis showed a significant interaction between Group x Time on both the BDI $(p<0.01)$ and EROS $(p<0.001)$ and large effect sizes on the BDI (1.61) and EROS $(1.14)$ demonstrated clinically significant improvements. There was a trend toward greater social support in the treatment group relative to control at post-treatment $(p=0.08)$ with a moderate effect size $(d=0.70)$. Reliable change indices were calculated for each measure and showed that $93 \%$ of individuals in the BATD group significantly improved on the BDI compared with $31 \%$ in the control group, that $64 \%$ of individuals in the BATD group significantly improved on the EROS compared to $0 \%$ of participants in the control group, and that $29 \%$ of individuals in the BATD group significantly improved on the MSPSS compared with $6 \%$ in the control group. Change-score data showed a strong relationship between increased environmental reward with decreased depression $(p<0.01)$, anxiety $(p<0.05)$, and increased social support $(p<0.01)$. Authors concluded that there was evidence that a brief BA intervention was effective in reducing depressive symptoms, increasing response-contingent positive reinforcement, and increasing social support. Data shows that a single-session of the BATD intervention resulted in significant reductions in depressive symptoms and increased environmental reward, suggesting that 
shortened treatments may be effective and efficient in reducing depressive symptoms of moderately depressed students.

The next article for review is a meta-analysis by Mazzucchelli, Kane, and Rees (2009). The purpose of this meta-analysis was to identify all randomized control trials (RCT) of behavioral activation (BA), establish the effect of this method, and compare the effectiveness of its variants. Interventions included pleasant activities, self-control, contextual behavioral activation, and Behavioral Activation Treatment for Depression (BATD). Comparators included nontreatment, cognitive behavioral therapy/cognitive therapy (CBT/CT), and a blanket group of other treatments such as psychodynamic therapy or supportive counseling. After exclusion, 34 studies with a total of 2,055 participants were chosen. Results showed a large overall effect size in patients with elevated scores of depressive symptoms favoring BA over control conditions. This finding is similar to previous meta-analyses. Results also show a large, significant overall effect size favoring BA in patients meeting criteria for depressive disorder. However, comparisons between BA and CBT/CT showed no difference at post-test or follow-up, indicating that these treatments were equally effective in the short- and long-term. From the evidence, authors concluded that BA interventions are effective for the treatment of depression in adults, and the behavioral activation approach could be designated as a well-established treatment for depression.

The next article for review by Richards, et al. (2016) is a randomized, controlled, openlabel, noninferiority trial. The purpose of this study was to assess clinical efficacy and costeffectiveness of BA intervention compared to CBT in adults with depression. Patients were randomly assigned to treatment groups using computer-generated randomization and were stratified by depression severity according to PHQ-9 scores, antidepressant use/nonuse, and 
recruitment site. The BA intervention was delivered to participants by junior Mental Health Workers (MHWs) and the CBT intervention was delivered by experienced psychologists. Follow-up assessments were conducted at six, 12, and 18 months. The primary outcome measure was self-reported depression severity using the PHQ-9 at 12 months. Secondary outcome measures included PHQ-9 scores at six and 18 months, diagnostic status, number of depression free days between follow-up points as determined by structured clinical interview, and healthrelated quality of life at six, 12, and 18 months using a 36-Item Short Form Survey. The modified intention-to-treat (mITT) population is comprised of all participants randomized with complete data and the per-protocol (PP) population was comprised of participants randomized with complete data who completed at least eight treatment sessions. Authors found no evidence of inferiority between these two populations. Authors also found no evidence of a significant between-group treatment interaction across the mITT or PP group for the primary outcome at 12 months as stratified by depression severity, antidepressant use, and recruitment site. Data showed that BA was not significantly different from CBT with relation to anxiety, depression status, depression-free days, or anxiety diagnoses for either the mITT or PP populations at 12 months. Data also showed that $61 \%$ to $70 \%$ of mITT and PP participants in both treatment groups met the criteria for recovery from depression with response to treatment at 12 months. Authors found no evidence of a difference between the BA and CBT groups with a nonsignificant time by treatment effect interaction for both mITT and PP populations. Authors did find a significant difference in average cost for intervention between the two groups in favor of BA $(p<0.0001)$, but no differences between categories of cost (hospital care, community health care, or medication) or in total cost. The mean health-related quality of life score was slightly higher for participants in the BA group at all follow-up points with resulting quality-adjusted life years 
(QALY) also higher for participants in BA. Authors concluded that BA treatment for depression is non-inferior to CBT in terms of reduction in depressive symptoms and is more cost-effective than CBT treatment. Overall, authors believe that the results of this study challenge the dominance of CBT due to findings that suggest therapies that can reduce the need for costly professional training, reduce patient waiting times, and increase access to psychological therapies.

The next article for review is a benchmark-controlled trial (BCT) by Luoto et al. (2018). The purpose of this study is to examine the effects of BA in a group of depressed patients in their natural treatment setting and compare them to treatment as usual with regard to functional recovery, service use, dropout rate, and mortality. After matching, authors found that statistically significant differences between groups were baseline Global Assessment of Functioning (GAF) scores and frequency of personality disorders as a secondary diagnosis. BA treatments were implemented by trained personnel, including registered psychiatric nurses, psychiatric practical nurses, and psychologists. Follow-up appointments were scheduled with a clinical research nurse at six, 12, and 24 months after intervention. Patients in the control group received TAU according to the protocols of their specific interventions and follow-up data was gathered from patient case-notes at six, 12, and 24 months after treatment by estimating GAF scores and obtaining information about alcohol use. For treatment and control conditions, data concerning frequency of outpatient visits, number of hospital days, and dropout rates were obtained from patient records at six, 12, and 24 months following treatment. Results showed that mean scores for participants in the treatment group on MADRS at baseline was 23.2 points, 13.1 points at 6 months, 9.93 points at 12 months, and 8.31 points at 24 months. The improvement of MADRS scores for treatment group participants was statistically significant in every follow-up period. 
Again, for treatment group participants there was no difference in GAF scores between baseline and follow-up at six months. However, at 12- and 24-months follow-up the estimated improvement in GAF scores was significantly better in the intervention group $(p=0.036)$. Data showed no between-group differences in number of outpatient visits during any follow-up period. The need for hospitalization was similar between treatment and control groups during all follow-up periods. There were no differences between treatment and control groups with regards to dropout rates in any follow-up period ( $p=0.79, p=0.86, p=0.51$, respectively). During all follow-up periods, there was no significant difference in mortality between groups $(p=0.23)$. Authors consider this study to be highly representative of the standard patient population in natural practice settings. Due to this capability for generalization, they believe conclusions are useful in real world practices. Data from this study shows that depressive symptoms of participants in the treatment group seemed to improve at follow-up periods, and the authors believe that BA may be a useful tool for treatment. Authors also noted that participants in the treatment group showed a greater improvement in functional ability than those in the control group and believe this is essential to patients' daily life. Rates of hospitalization and dropout were not significantly different between treatment and control groups. Overall, authors found an improvement in depressive symptoms and a trend toward functional recovery in patients treated with BA compared to TAU.

The last article for review by Funderburk, Pigeon, Shepardson, and Maisto (2019) was a non-randomized, non-controlled intervention trial. The purpose of this study was to address the need for a brief depression treatment suitable for primary care. Data showed a significant reduction in depressive symptoms based on PHQ-9 scores $(p=0.001)$. Data also revealed patient engagement of $36 \%, 1 \%$, and $32 \%$ at appointments two, three, and four respectively based on 
completed activity logs. A CSQ rating of 26.7 out of 35 indicated a high level of patient satisfaction, including satisfaction with the number, duration, and format of appointments. Authors concluded that results of the study supported the feasibility, acceptability, and efficacy of BA-PC. Patients reported high levels of satisfaction with the intervention, high likelihood of continuing activity scheduling after treatment, and perceived improvements in depressive symptoms which was supported by a decrease in PHQ-9 scores. Authors do admit that BA-PC may not entirely resolve depressive symptoms, and that a majority of patients did not report a clinically significant reduction in symptoms as defined by their criteria; however, a $68 \%$ treatment response showed a majority of patients reported symptom reduction. Summarily, this study showed BA-PC was well received by patients, could be delivered with high fidelity, and may result in an improvement of depressive symptoms.

\section{Literature Synthesis}

This review produced studies that were mostly located in the upper tiers of evidence-based literature with a majority being randomized control trials or meta-analyses. All articles were published in peer-reviewed journals lending credibility to study findings. They were also replicable and generalizable. While not all studies found behavioral activation to be superior to cognitive-behavioral therapy or cognitive therapy, all studies found BA to be equivalent to CBT/CT. All studies also found BA to be superior to placebo, control, antidepressant medication, and other forms of psychosocial intervention.

\section{Theoretical Framework}

This project was based on the Theory of Symptom Management. The Theory of Symptom Management was first introduced in 1994 by faculty at UCSF School of Nursing and revised in 
2001. According to the theory, signs and symptoms of illness disrupt functioning and bring patients into the health care system, usually after self-care management strategies fail. This theory proposes a relationship between three concepts, provides a structure to understand the relationship between concepts, and provides a framework for considering interventions and outcomes (Smith \& Liehr, 2008).

The Theory of Symptom Management is composed of three concepts. These concepts include symptom experience, symptom management strategies, and symptom status outcomes. Symptom experience is the "simultaneous perception, evaluation, and response to a change in usual feeling" (Smith \& Liehr, 2008, p. 147). If a symptom occurs with enough frequency and severity to be perceived as distressing and interfering with life, the patient will seek help for more effective ways to minimize or stop the symptom. Symptom management strategies are "efforts to avert, delay, or minimize symptom experience" (Smith \& Liehr, 2008, p. 147). Management strategies are effective by reducing frequency of symptom experience, minimizing severity of symptom experience, and relieving the distress associated with symptom experience. Symptom status outcomes are specific, measurable outcomes that are evaluated after the implementation of a strategy. Outcomes are obvious changes in symptom status where the symptom is less frequent, intense, or distressing (Smith \& Liehr, 2008).

This theory is a framework for the study and development of symptom management strategies and apply to this project. Theoretically, patients with low socioeconomic status will experience depressed mood, anhedonia, and other symptoms of depression (Brody, Pratt, \& Hughes, 2018). These symptoms cause the patient to suffer some type of distress. They then try to manage or eliminate this distress on their own but frequently visit their primary care provider when self-management is inadequate. Primary care providers then enact interventions that have 
been shown to alleviate or eliminate symptom experience. In this situation, it seems that typical management strategies are not adequate to improve symptom experience. Successful interventions by the primary care provider should improve the distress of depression symptoms. Using this framework, new interventions can be implemented and evaluated for symptom management strategy.

\section{Project}

\section{Intervention Plan}

Treatment guidelines from the National Institute for Health and Care Excellence recognize that BA is an effective treatment for depression and should be considered as an intervention for patients with depressive symptomology ([NICE], 2009). This pilot study evaluated the effectiveness of the revised Behavioral Activation Treatment for Depression (Lejuez, Hopko, Acierno, Daughters, \& Pagoto, 2011) combined with treatment as usual implemented in a predominantly free primary care clinic in northern West Virginia serving a population of individuals with a low socioeconomic status.

The intervention used in this pilot study was a shortened version of the revised Behavioral Activation Treatment for Depression (BATD-R) by Lejuez, Hopko, Acierno, Daughters, and Pagoto (2011). Direction was taken from the revised treatment manual. Specific revisions to the revised treatment include greater emphasis on treatment rationale, more clarity on life areas, values, and activities, simplified and fewer treatment forms, enhanced procedural details, and a revised daily monitoring form for low literacy (Lejuez, Hopko, Acierno, Daughters, \& Pagoto, 2011). The original procedure in its extended format consists of 10 sessions. These meetings include five active treatment sessions and five sessions for review and post-treatment planning. 
(Lejuez, Hopko, Acierno, Daughters, \& Pagoto, 2011). Studies have shown the effectiveness of BA in as little as one to two sessions (Gawrysiak, Nicholas, \& Hopko, 2009; Funderburk, Pigeon, Shepardson, \& Maisto, 2019) which led this intervention to consist of the five active sessions from the BATD-R treatment manual according to instruction. Sessions took place during 60-minute appointments once weekly for five weeks. This intervention took place at a predominantly free primary care clinic in northern West Virginia where appointment length is usually 60 minutes.

Patients with a provider appointment set between April 26, 2020 and July 24, 2020 were screened for eligibility by the provider using the electronic medical record. Eligibility criteria for patient participation was a diagnosis of major depressive disorder or elevated depressive symptomology as evidenced by answering yes to either question on the PHQ-2. Exclusion criteria included participation in any other psychosocial treatment. Each patient who agreed to take part in the project was asked to sign an informed consent document.

During the first treatment session, each patient completed a Patient Health Questionnaire-9 (PHQ-9) and Behavioral Activation for Depression Scale (BADS) questionnaire. Throughout treatment, patients completed Daily Monitoring Forms (DMF), the Life Areas, Values, and Activities Form (LVAF), the Activity Selection and Ranking Form (ASRF), and Contract Forms (CF). The DMF is a table that allows the patient to track their daily activities (see Appendix B). The LVAF is a form the patient can use to identify their values in certain life areas and specific activities that support these values (see Appendix C). The ASRF is a form the patient uses to choose activities that support their values and then ranks these activities by difficulty (See Appendix D). The CF is a form that patients use to encourage involvement from family and 
friends in their treatment (Appendix E). Each session in the revised manual was accompanied by a completion checklist for the provider.

Each session in the revised manual was accompanied by a completion checklist for the provider.

- Session one included a discussion of depression, introduction to treatment rationale and the daily monitoring form, and important points about the structure of treatment.

- Session two included reviewing and troubleshooting the DMF, reviewing the treatment rationale, and completing the LVAF.

- Session three included reviewing DMFs, reviewing the LVAF, and completing the ASRF.

- Session four included reviewing DMFs and starting daily monitoring with planning activities.

- Session five included reviewing DMFs with activity planning, completing the CFs, and completing a DMF for the week with activity planning.

- Subsequent sessions included the continuation of review and activity planning.

Data from the completed PHQ-9 and BADS questionnaires pre- and post-intervention were kept in a data table using random patient identification numbers, accompanied by a separate master list. (Refer to Appendix F for data table.) This data table and master list was kept in a locked box with a key kept by the project leader. All other documents completed by the patient were stored in their electronic medical record.

Participating patients were supposed to attend five 60-minute sessions over the course of five weeks. All visits were conducted according to the BATD-R manual. The provider completed 
a checklist for each session to ensure adherence to treatment. It was intended for each patient to complete a post-treatment PHQ-9 and BADS during the last treatment session. Patients who failed to attend at least three out of five treatment sessions were considered lost to follow-up.

\section{Feasibility Analysis}

The goal of this pilot study was to implement a behavioral activation intervention in the primary care setting to improve the management of depression. It was implemented in a community funded clinic that services low income, uninsured and underinsured patients. This clinic is housed in the center of an urban area where most community resources reside for the impoverished population. These resources include multiple food pantries and soup kitchens, a drop-in center, homeless shelter, and department of human resources. The clinic itself serves as a meeting place for a large portion of this population since most of the homeless population can be found in this area. A significant number of patients who attend this clinic pass through multiple times a day. While the location of this clinic is ideal for its population, most specialty clinics can only be accessed using automotive transportation. Patients at this clinic rarely have funds for bus rides, car services, or personal vehicles. Most patients will usually request continued treatment at the primary care clinic.

In order to provide comprehensive behavioral activation treatment, one provider spent about 60 minutes per session for a varying number of sessions with five patients. The provider saw patients during usual clinic visits and evaluated PHQ-9 scores during the patient assessment so provider salary was by the clinic as an organizational contribution. The budget for administrative costs totaled approximately $\$ 3,000$. 
Educational materials were available for the provider. The provider had a copy of the BATD-R treatment manual. Session checklists from the treatment manual were used for each individual patient. The scripts for depression discussion and treatment rationale from the first session of the treatment manual were printed for each patient to use for discussion. Allowing for error in printing, the budget for educational materials totaled approximately $\$ 45$ from the project leader's personal funds.

Project supplies consisted of necessary materials for project intervention. These supplies included two copies of the PHQ-9 and BADS, one daily monitoring form, one Life Areas, Values, and Activities form, one Activity Selection and Ranking form, and two contract forms per patient. These documents were kept in individually labeled file folders and all were kept in a locked box. Pens were available for use by participating patients. Estimations take into account printing errors. The budget for project supplies totaled approximately $\$ 75$ from the project leader's personal funds.

The budget for this project totaled approximately $\$ 3,120$. A majority of this budget was collected from an organizational contribution and the rest from the project leader's personal funds. This includes monetary provisions for administrative costs, educational materials, and project supplies. Implementation and organizational costs to the clinic were minimal since the project leader is employed by the clinic and the intervention will be reimbursable as a normal clinic visit. Contributions from the clinic were reflected as a portion of the current salary of the provider already in place for provision of care. Return on investment was minimal for the clinic due to the number of uninsured patients, but some income was generated by billing these visits for Medicaid patient participants. However, insurance status was not considered when recruiting participants for this project. 
There were a few identifiable potential barriers to this project. The first potential barrier was the need for increased appointments with the patient. The author considered that increasing the number of follow-up appointments might put undue pressure on patients in this population and lead to failed outcomes. This is similar to the barrier of patient compliance. As with most populations, compliance with an aggressive treatment is likely to be low since it requires increased patient effort and participation. The last barrier is patient literacy, including health literacy. Patients in a low SES population tend to have low literacy levels, including health literacy. This potentially impacted patient understanding of the disease process and treatment rationale, and their ability to use written forms for monitoring. This last potential barrier was addressed in the revised manual of BATD.

\section{Evidence of Site Support}

Support for this project was provided by the administration and clinical staff at the clinic of interest. The clinic director gave written approval for the project to take place at the clinic. Refer to Appendix G for evidence of site support.

\section{Timeline}

Planning for this project started in August of 2019. The study was enrolled in IRB and approved in April of 2020. It was also enrolled in the Clinical Trials Center of Excellence and the protocol was approved in July of 2020. Implementation began near the end of April 2020 during the COVID-19 pandemic and was completed near the end of July 2020. Due to issues arising from the pandemic, enrollment in the project was extended by four weeks. The project was concluded in August 2020. Refer to Appendix H for evidence of timeline.

\section{Measurable Project Objectives}


The first aim of this project was to assess the feasibility of implementing this intervention in this clinic population with a large percentage of patients struggling with mental illness, who were potentially homeless, had a low income, and were either uninsured or underinsured. There were five feasibility measures as denoted by Bowen et al. (2009) that were used as measurable objectives for this aim: acceptability, demand, implementation, practicality, and limited-efficacy testing. Acceptability is the extent to which an intervention is judged as suitable to the patient and was measured by the intent to continue use of the intervention (Bowen et al., 2009). Demand is the extent to which an intervention is likely to be used and was measured by the expressed interest in the intervention and its actual use (Bowen et al., 2009). Implementation is the extent to which an intervention is successfully delivered to patients and was measured by the success or failure of its execution (Bowen et al., 2009). Practicality is the extent to which an intervention can be carried out using the existing resources and was measured by the ability of the participants to complete intervention activities (Bowen et al., 2009). Limited-efficacy testing is whether or not the intervention can be successful in the intended population and was measured by the presence of the intended effects on key variables (Bowen et al., 2009). Data gathered from implementation of the intervention and patient participation was used to assess these objectives.

The second aim of this project was to decrease overall PHQ-9 scores and increase overall BADS scores using a psychosocial intervention. There were two measurable objectives for this aim: patients with depression will show a decrease in overall PHQ-9 scores post-intervention, and patients with depression will show an increase in BADS scores post-intervention. Data for these objectives were measured using self-report information from the PHQ-9 questionnaire and BADS questionnaire. Overall PHQ-9 scores and BADS scores were assessed before intervention 
for all patients, and after intervention for some patients. A paired $t$-test was used to determine if there was a statistical difference between the pre- and post-data.

The third aim of this project was to increase medication treatment adherence in conjunction with a psychosocial intervention. There was one measurable objective for this aim: patients with depression will show an increase in medication treatment adherence postintervention. Data for this objective was supposed to be measured using self-report information and pill counts during the first follow-up visit.

\section{Data Analysis}

Once post-treatment questionnaires were completed, data analysis began. Overall PHQ-9 and BADS scores were calculated for pre- and post-intervention data. Paired $t$-tests were used to determine differences between them. Adherence to treatment by provider was measured using checklists from each session to determine percentage of completion.

\section{Results}

\section{Participation Summary}

Patients were eligible for participation if they had a diagnosis of major depressive disorder or elevated depressive symptomology as evidenced by answering yes to either question on the PHQ-2. Exclusion criteria included participation in any other psychosocial treatment and individuals less than 18 years of age. Five eligible patients agreed to participate in the study. Ten eligible patients declined to participate in the study. All other patients with a diagnosis of MDD or depressive symptomology were being seen by a counselor for other psychosocial treatment, making them ineligible for BATD-R. 


\section{Treatment Summary}

\begin{tabular}{|c|c|c|c|c|}
\hline $\begin{array}{l}\text { Patient Number } x \\
\text { Number of Sessions }\end{array}$ & Pt. 1 & Pt. 2 & Pt. 3 & Pt. 4 \\
\hline Sn. 1 & $X$ & $X$ & $X$ & $X$ \\
\hline Sn. 2 & $X$ & & $X$ & \\
\hline Sn. 3 & $X$ & & & \\
\hline $\mathrm{Sn} .4$ & X & & & \\
\hline Sn. 5 & $X$ & & & \\
\hline
\end{tabular}

Four patients were enrolled in the project study, and one patient made a verbal commitment with a scheduled appointment to start the study. The first patient completed five sessions of BATD-R and elected to continue with several sessions. The second patient completed one session of BATD-R and then declined further participation. This patient has not been seen in the clinic since the first session of BATD-R and no reason was given for discontinuing treatment. The third patient completed two sessions of BATD-R, but the next session was cancelled by the clinic due to COVID. The subsequent follow-up appointment was cancelled by the patient. Upon resumption of treatment, this patient elected to postpone further follow-up due to a recent death in the family. The fourth patient completed one session of BATD-R, but the next session was cancelled by the clinic due to COVID. The patient then missed the next clinic appointment and was unable to be reached by phone later in the week after rescheduling. This patient has not been seen in the clinic since missing the follow-up appointment. The fifth patient did not attend the first session of BATD-R and has not been seen in the clinic since agreeing to participate in the study. 


\section{Demographic Data Summary}

Demographic data was obtained for three of the five participants. The second patient did not provide demographic data and the fifth patient was not seen for the initial visit when demographic data collection takes place. Demographic data included age, gender, ethnicity, level of education, employment, housing, tobacco use, drug use, and alcohol use. Patients ranged in age from 27 to 61 years old. Two patients were female, two patients are male. Three patients considered themselves white. Level of education ranged from ninth grade to some college. Two patients were unemployed, one patient was employed. Three patients lived with another person. Two patients rented their residence and one patient owned their residence. Two patients lived in a house and one patient lived in an apartment. Two patients smoked cigarettes and one patient did not use tobacco. Two patients used illicit drugs and one patient did not. Two patients did not use alcohol and one patient did use alcohol.

\section{Evaluation Results}

$\underline{\text { Aim } 1}$ - The first aim of this project was to assess the feasibility of implementing this intervention using five measurable objectives: acceptability, demand, implementation, practicality, and limited-efficacy testing. Acceptability is the extent to which an intervention is judged as suitable and was measured by the intent of participants to continue use of the intervention. Only one participating patient attended the five required sessions of BATD-R, while one patient completed two sessions, two patients completed one session, and one patient completed zero sessions. The patient who completed five sessions elected to continue with several sessions of BATD-R after the first five sessions. No other participants elected to continue treatment. This means that $20 \%$ of the participants intended to continue use of the intervention. 
Demand is the extent to which an intervention is likely to be used, and was measured by the expressed interest in the intervention and its actual use. Fifteen patients were eligible for the project intervention, but only five elected to participate. Of those five patients, four attended at least one session. This indicates that $33 \%$ of eligible patients expressed interest in the intervention, and $80 \%$ of those who expressed interest completed at least one session. However, only one patient completed all treatment sessions out of the five patients who expressed interest. This means that only $20 \%$ of the patients who expressed interest completed the intervention.

Implementation is the extent to which an intervention is successfully delivered to patients and is measured by the success or failure of its execution. Session checklists provided in the BATD-R manual were kept for each patient during sessions. Each checklist showed that all elements of each session were completed with the patient. This indicates that $100 \%$ of the required components for treatment were delivered to patients during treatment sessions.

Practicality is the extent to which an intervention can be carried out using the existing resources and is measured by the ability of the participants to complete intervention activities. Participants were expected to complete one Daily Monitoring Form every day, one Life Areas, Values, and Activities Form, one Activity Selection and Ranking Form, and at least one Contract Form. Patients were provided with one copy of each form, and expected to secure their own further copies of daily monitoring forms. Revised versions of the DMF for low literacy participants were offered to each patient, but all patients declined. Out of the four patients who attended the first session, three were capable of completing the DMF. This indicates that $75 \%$ of participating patients could use the DMF. One patient had difficulty with the DMF because she was illiterate. This indicates that $25 \%$ of participating patients could not use the DMF. Out of the two patients who attended the second session, one had no difficulty using the LAVF while the 
second exhibited some confusion at using the form. This indicates that $50 \%$ of the participating patients could use the LAVF form while $50 \%$ could not use the form. Of the one patient who completed the other three sessions, there was no difficulty in using the ASRF or the CFs. This indicates that $100 \%$ of the participating patients could use the ASRF and the CFs.

Limited-efficacy testing refers to whether or not the intervention can be successful in the intended population and is measured by the presence of the intended effects on key variables. Results for the effects of the intervention on key variables is limited due to high attrition rates and missing data. From the complete pre- and post-data of one patient who completed the intervention, there was a decrease in the PHQ-9 score and increase in the BADS score. From the partial pre- and post-data of one patient who completed two sessions of the intervention, there was an increase in the PHQ-9 score. There were no comparable data sets for the remaining three participants. This indicates that the intervention had the intended effect on key variables in $25 \%$ of the participating patients who completed at least one session.

$\underline{\text { Aim } 2}-$ The second aim of this project was to decrease depression scores and increase daily functioning scores as measured by the PHQ-9 and BADS questionnaires. Due to attrition, only one patient completed pre- and post-data for both PHQ-9 and BADS questionnaires, while one patient completed pre- and post-data for the PHQ-9 questionnaire. The average pre-intervention PHQ-9 score for all participating patients was 15.25, while the average pre-intervention BADS score for the same patients was 19. The average post-intervention PHQ-9 score for two of the four participating patients was 12. Missing data did not allow for an average of the postintervention BADS score of participating patients. In the patient that completed the intervention, the pre-intervention PHQ-9 score was 19 and the post-intervention score was 9. In this same patient, the pre-intervention BADS score was 17 and the post-intervention score was 35 . In the 
patient that completed two sessions of the intervention, the pre-intervention PHQ-9 score was 14 and the post-intervention score was 15 . A paired $t$-test was used to compare pre- and postintervention scores for two participating patients on the PHQ-9. There was no significant difference between the pre- and post-intervention PHQ-9 scores with $p=0.563$. However, PHQ9 and BADS scores showed clinically significant improvements in depressive symptoms and daily functioning in the patient who completed the intervention. The PHQ-9 scores showed no clinically significant differences in the patient who completed two sessions of the intervention.

$\underline{\text { Aim } 3}$ - The third aim of this project was to increase medication treatment adherence in conjunction with a psychosocial intervention. This data was unable to be collected and the provider was unable to determine if there was a statistical difference between the pre- and postdata.

\section{Discussion and Recommendations}

The theoretical framework for this project was based on The Theory of Symptom Management. This theory provides a framework for exploring the relationship between interventions and outcomes, as outlined by the structure of the association between symptom experience, symptom management strategies, and symptom status outcomes (Smith \& Liehr, 2008). According to The Theory of Symptom Management, patients experience distressing symptoms and seek symptom management strategies that are followed by an evaluation of symptom status outcomes where the symptom should be less frequent, intense, or distressing (Smith \& Liehr, 2008). The development, implementation, and evaluation of interventions is supported by this framework due to its association between the concepts of symptoms, as interventions are intended to improve symptoms. It is an especially apt framework for this 
project as it focuses on the evaluation of symptom outcomes after implementing an intervention for symptom relief.

The feasibility evaluation of this project showed mixed results. Data suggests that the intervention was not acceptable to the patient population, nor in high demand. Only a small number of eligible patients were interested in the intervention, and an even smaller amount actually participated in the sessions. Of those interested, only one patient completed the intervention. While data for implementation suggests the intervention can be successfully delivered, practicality seemed to be an issue. Completing the included intervention activity forms was essential to success of the treatment and patients seemed to struggle with understanding the required forms. Limited efficacy data also suggested that this intervention may not produce the expected improvement in symptoms of depression or daily functioning in this population.

Producing adequate data for analysis of significance was difficult due to patient attrition. Available data suggested there was no statistically significant difference in depressive symptoms or daily functioning between pre- and post-intervention. Yet data did indicate a potential clinical significance. The patient who completed two sessions of the intervention did not show a clinically significant difference in depressive symptoms; however, data from the patient that completed the intervention in its entirety suggested a clinically significant improvement in depressive symptoms and daily functioning after the intervention.

While there were some promising findings, it is recommended that this project be phased out and terminated at this facility. The feasibility of this project in a population of low income, uninsured and underinsured patients is questionable. Patient interest in this behavioral treatment was limited and data showed no statistically significant improvement in depression or functioning. Also, this project did not produce enough data to determine clinical significance. 
Patient interest in mental health treatment may have been eclipsed by the COVID-19 pandemic at this time. It could also account for the attrition rate of participating patients. When speaking of attrition, it is important to note that patients with mental illness are more likely to miss follow-up appointments, and those that miss follow-up appointments have a greater chance of losing contact with the clinic (DeFife, Conklin, Smith, \& Poole, 2010; Killaspy, Banerjee, King, \& Lloyd, 2000). These factors may have had an impact on the implementation of this project. It may be possible to implement this project in a behavioral health center or integrated care center, or a different primary care clinic with a population of patients that are more likely to attend frequent clinic visits. Patients attending a behavioral health center may be more likely to continue follow-up while patients at an integrated care center would receive comprehensive care that may encourage continued clinic contact. Research literature shows that behavioral activation is an effective treatment for depression but this project demonstrates that it may not be appropriate in a low-income primary care clinic, especially during the COVID-19 pandemic.

The implementation of this project has positively impacted the care I provide for patients with mental illness. The research undertaken during the planning phase of this project has allowed me to more thoroughly understand the assessment and diagnosis of depression. It has also allowed me greater knowledge of the available treatments for depression and their relative effectiveness. The therapeutic relationships I built during the implementation phase of this project has led me to greater empathy and compassion for patients with mental illness. Greater understanding of the patients' experience has improved my communication and allowed for enhanced patient motivation. While analyzing feasibility and outcomes of this project during the resolution phase I was able to better understand what patients desire from their treatment plan and the capabilities of this population to engage in their treatment. The outcomes of this project 
suggest that patients in this population desire more of a therapeutic approach and are not highly engaged in treatment activities. This realization led me to increase my use of motivational interviewing techniques leading patients to higher levels of engagement and change. These modifications in my practice are directly related to the knowledge I gained from this project. 


\section{DNP Essentials}

This project meets the first essential of "scientific underpinnings for practice" by using nursing theory to evaluate practice approaches in a novel environment. Using the Theory of Symptom Management, this psychosocial intervention was further developed and its effectiveness validated in the primary care setting.

This project meets the second essential of "organizational and systems leadership for quality improvement and systems thinking" by developing and evaluating care for certain vulnerable populations. This psychosocial intervention has been revised for patients with mental illness who belong to a low socioeconomic status or lack adequate healthcare coverage.

This project meets the third essential of "clinical scholarship and analytical methods for evidence-based practice" by critically appraising existing literature and using synthesized information to design and implement methodologies that promote effective patient care. The literature review of this psychosocial intervention preceded the revision of intervention guidelines which were implemented to promote patient wellness.

This project meets the fourth essential of "information systems/technology and patient care technology for the improvement and transformation of health care" by demonstrating the ability to develop and execute an evaluation plan using data extraction from practice information systems. Completed health questionnaires used to evaluate the effect of this intervention became part of the patient's medical chart, and data from these documents were used to evaluate intervention efficacy.

This project meets the fifth essential of "health care policy for advocacy in health care" by developing and implementing institutional health care policy. This psychosocial intervention has 
the potential to become part of treatment guidelines for this population and become institutional policy at primary health care clinics. The findings from this project can help to improve the implementation of this intervention.

This project meets the sixth essential of "interprofessional collaboration for improving patient and population health outcomes" by using effective communication and collaboration in the development and implementation of practice guidelines. The project leader improved the use communication skills to educate clinic providers and clinic staff on the use of this intervention and encouraged collaborative teamwork to make it successful.

This project meets the seventh essential of "clinical prevention and population health for improving the nation's health" by including education as part of the intervention to promote healthy behaviors that have an effect on population health. Using a psychosocial intervention, this project promoted healthy behaviors in depressed patients that have an effect on this particular population.

This project meets the eighth essential of "advanced nursing practice" by demonstrating advanced levels of clinical judgment, systems thinking, and accountability in designing, delivering, and evaluating evidence-based care to improve patient outcomes by designing, implementing, and evaluating a psychosocial intervention in primary care. The project leader revised the design, implemented, and evaluated an evidence-based psychosocial intervention that can improve patient outcomes.

Nurses are known to value the holistic well-being of their patients. They establish therapeutic relationships that promote a mutual trust and respect between patient and nurse. This relationship often allows the patient to become an equal partner in their care and encourages 
participation in treatment. This is a unique attribute of the advanced practice nurse. The intervention utilized in this study was a direct reflection of that partnership between provider and patient and appropriate for use by advanced practice nurses. 


\section{References}

American Association of Colleges of Nursing. (2006). The essentials of doctoral education for advanced nursing practice. Washington, DC: Author.

American Psychiatric Association. (2013). Diagnostic and statistical manual of mental disorders (5th ed.). Arlington, VA: American Psychiatric Association.

American Psychological Association. (2020). Depression. American Psychological Association. https://www.apa.org/topics/depression\#

Bowen, D.J., Kreuter, M., Spring, B., Cofta-Woerpel, L., Linnan, L., Weiner, D., Bakken, S., Kaplan, C.P., Squiers, L., Fabrizio, C., \& Hernandez, M. (2009). How we design feasibility studies. American Journal of Preventive Medicine, 36(5), 452-457. Doi:10.1016/j.amepre.2009.02.002.

Brody, D.J., Pratt, L.A., \& Hughes, J.P. (2018). Prevalence of depression among adults aged 20 and over: United States, 2013-2016. Retrieved from https://www.cdc.gov/nchs/products/databriefs/db303.htm

Centers for Disease Control and Prevention (2015). Depression. Retrieved from https://www.cdc.gov/nchs/fastats/depression.htm

Centers for Disease Control and Prevention (2018). Stats of the State of West Virginia. Retrieved from https://www.cdc.gov/nchs/pressroom/states/westvirginia/westvirginia.htm 
Coryell, W. (2018). Unipolar depression in adults: Course of illness. Retrieved from https://www.uptodate.com/contents/unipolar-depression-in-adults-course-ofillness?search=major\%20depressive $\% 20$ disorder\%20and\%20sleep\&source=search_result $\&$ selectedTitle $=1 \sim 150 \&$ usage_type $=$ default $\&$ display_rank $=1$

Cuijpers, P., van Straten, A., \& Warmerdam, L. (2007). Behavioral activation treatments of depression: A meta-analysis. Clincal Psychology Review, 27, 318-326. Doi: 10.1016/j.cpr.2006.11.001

C. Wang, personal communication, December 15, 2019

DeFife, J., Conklin, C., Smith, J., \& Poole, J. (2010). Psychotherapy appointment no-shows: Rates and reasons. Psychotherapy: Theory, Research, Practice, Training, 47, 413-417. Doi:10.1037/a0021168

Dimidjian, S., Hollon, S.D., Dobson, K.S., Schmaling, K.B., Kohlenberg, R.J., Addis, M.E., Gallop, R., McGlinchey, J.B., Markley, D.K., Gollan, J.K., Atkins, D.C., Dunner, D.L, \& Jacobson, N.S. (2006). Randomized trial of behavioral activation, cognitive therapy, and antidepressant medication in the acute treatment of adults with major depression. Journal of Counseling and Clinical Psychology, 74(4), 658-670. Doi: 10.1037/0022

006X.74.4.658

Dobson, K.S., Hollon, S.D., Dimidjian, S., Schmaling, K.B., Kohlenberg, R.J., Gallop, R.J., 
Rizvi, S.L., Gollan, J.K., Dunner, D.L., \& Jacobson, N.S. (2008). Randomized trial of behavioral activation, cognitive therapy, and antidepressant medication in the prevention of relapse and recurrence in major depression. Journal of Consulting and Clinical Psychology, 76(3), 468-477. http://dx.doi.org.www.libproxy.wvu.edu/10.1037/0022 006X.76.3.468

Ekers, D., Richards, D., \& Gilbody, S. (2008). A meta-analysis of randomized trials of behavioural treatment of depression. Psychological Medicine, 38, 611-623. Doi:10.1017/S0033291707001614

Ferster, C.B. (1973). A functional analysis of depression. American Psychologist, 28, 857-870.

Funderburk, J.S, Pigeon, W.R., Shepardson, R.L., \& Maiso, S.A. (2019). Brief behavioral activation intervention for depressive symptoms: patient satisfaction, acceptability, engagement, and treatment response. Psychological Services, 1-9. http//dx.doi.org/10.1037/ser0000328

Gawrysiak, M., Nicholas, C., \& Hopko, D.R. (2009). Behavioral activation for moderately depressed university students: Randomized control trial. Journal of Counseling Psychology, 56(3), 468-475. Doi: 10.1037/a0016383

Hellebuyck, M., Halpern, M., Nguyen, T., \& Fritze, D. (2019). Mental health workforce availability. In The State of Mental Health in America. Retrieved from 
https://mhanational.org/sites/default/files/2019\%20MH\%20in\%20America\%20

Final_0.pdf.

Killaspy, H., Banerjee, S., King, M., \& Lloyd, M. (2000). Prospective controlled study of psychiatric out-patient nonattendance: Characteristics and outcome. The British Journal of Psychiatry, 176, 160-165.

Krishnan, R. (2019). Unipolar depression in adults: Epidemiology, pathogenesis, and neurobiology. Retrieved from https://www.uptodate.com/contents/unipolar-depression-inadults-epidemiology-pathogenesis-and-neurobiology?search=depression\%20pathogenesis $\&$ source=search_result\&selectedTitle=1 150\&usage_type=default\&display_rank=1

L. Jones, personal communication, December 15, 2019

Lejuez, C.W., Hopko, D.R., Acierno, R., Daughters, S.B., \& Pagoto, S.L. (2011). Ten year revision of the brief behavioral activation treatment for depression: Revised treatment manual. Behavioral Modification, 35(2), 111-161. Doi: 10.1177/0145445510390929

Lewinsohn, P.M. (1974). A behavioral approach to depression. In R.M. Friedman, \& M.M. Katz (Eds.), The Psychology of depression: Contemporary theory and research. New York: Wiley

Luoto, K.E., Lindholm, L.H., Paavonen, V., Koivukangas, A., Lassila, A., Leinonen, E., \& Kampman, O. (2018). Behavioral activation versus treatment as usual in naturalistic 
sample of psychiatric patients with depressive symptoms: A benchmark controlled trial. BMC Psychiatry, 18(238), 1-7. https://doi.org/10.1186/s12888-018-1820-x

Mauer, B. (2006). Morbidity and mortality in people with serious mental illness. Series of Technical Reports, 13, 1-11. Retrieved from https://www.nasmhpd.org/sites/default/files/Mortality\%20and\%20Morbidity \%20Final\%20Report\%208.18.08.pdf

Mazzucchelli, T., Kane, R., \& Rees, C. (2009). Behavioral activation treatments for depression in adults: A meta-analysis and review. Clinical Psychology: Science and Practice, 16(4), 383-411. Doi: 10.1111/j.1468-2850.2009.01178.x

McCrone, S., Cotton, S., Jones, L., Hawkins, T.A., Costante, J., \& Nuss, M. (2007). Depression in a rural, free clinic providing primary care: Prevalence and predictive factors. Archives of Psychiatric Nursing, 21(5), 291-293. Doi:10.1016/j.apnu.2007.06.009

National Institute for Health and Care Excellence. (2009). Depression in adults: Recognition and management. Retrieved from https://www.nice.org.uk/guidance/cg90/resources/depression-in-adults-recognition-and management-pdf-975742638037

Pratt, L.A., Brody, D.J., \& Gu, Q. (2017). Antidepressant use among persons aged 12 and over: United States, 2011-2014. Retrieved from 
https://www.cdc.gov/nchs/products/databriefs/db283.htm

Richards, D.A., Ekers, D., McMillan, D., Taylor, R.S., Byford, S., Warren, F.C., Barrett, B., Farrand, P.A., Gilbody, S., Kuyken, W., O’Mahen, H., Watkins, E.R., Wright, K.A, Hollon, S.D., Reed, N., Rhodes, S., Fletcher, E., \& Finning, K. (2016). Cost and outcome of behavioural activation versus cognitive behavioural therapy for depression (COBRA): A randomized, controlled, non-inferiority trial. The Lancet, 388, 871-880. http://dx.doi.org/10.1016/S0140-6736(16)31140-0

Smith, M.J., \& Liehr, P.R. (2008). Middle range theory for nursing (2nd ed.). New York, NY: Springer Publishing Company

Turner, J.S \& Leach D.J. (2012). Behavioural activation therapy: Philosophy, concepts, and techniques. Behaviour Change, 29(2), 77-96. Doi: 10.1017/bec.2012.3

WV Department of Health and Human Resources, Bureau for Behavioral Health and Health Facilities. (2016). Behavioral health epidemiological county profile: Monongalia county. Retrieved from https://dhhr.wv.gov/bhhf/Sections/ programs/ProgramsPartnerships/AlcoholismandDrugAbuse/Documents/ County\%20EPI\%20Profiles\%202017/2016\%20Monongalia\%20County $\% 20$ Profile\%20.pdf

WV Department of Health and Human Resources, Health Statistics Center. (2018). West 
Virginia behavioral risk factor surveillance system report, 2016. Retrieved from http://www.wvdhhr.org/bph/hsc/pubs/brfss/2016/BRFSS2016.pdf. 
Appendix A

\begin{tabular}{|c|c|c|c|c|c|c|}
\hline $\begin{array}{l}\text { Author/Da } \\
\text { te }\end{array}$ & $\begin{array}{l}\text { Purpose/Varia } \\
\text { bles }\end{array}$ & $\begin{array}{l}\text { Design/Meth } \\
\text { od }\end{array}$ & $\begin{array}{l}\text { Sample/Setti } \\
\text { ng }\end{array}$ & Data Analysis & Findings & $\begin{array}{l}\text { Apprais } \\
\text { al }\end{array}$ \\
\hline $\begin{array}{l}\text { Cuijpers, P., } \\
\text { van Straten, } \\
\text { A., \& } \\
\text { Warmerdam, } \\
\text { L. (2007). }\end{array}$ & $\begin{array}{l}\text { To examine the } \\
\text { effects of activity } \\
\text { scheduling on } \\
\text { depression, the } \\
\text { relative effects of } \\
\text { activity scheduling } \\
\text { compared to other } \\
\text { treatments, and the } \\
\text { long-term effects. }\end{array}$ & $\begin{array}{l}\text { Meta-analysis. } \\
\text { Comprehensive } \\
\text { literature search } \\
\text { (1966-2005) } \\
\text { through PubMed, } \\
\text { PsyclNFO, Embase, } \\
\text { and Cochrane } \\
\text { Central Register of } \\
\text { Controlled Trials. } \\
\text { Collected primary } \\
\text { studies from 22 } \\
\text { meta-analysis of } \\
\text { psychological } \\
\text { treatment of } \\
\text { depression. } \\
\text { Examined abstracts } \\
\text { of } 777 \text { studies and } \\
\text { selected ones } \\
\text { which focused on } \\
\text { activity scheduling. } \\
\text { Included studies in } \\
\text { which effects of } \\
\text { activity scheduling } \\
\text { on adults with a } \\
\text { depressive disorder } \\
\text { or an elevated level } \\
\text { of symptomology } \\
\text { were compared to } \\
\text { a control condition } \\
\text { or another } \\
\text { psychological or } \\
\text { pharmacological } \\
\text { treatment in a } \\
\text { randomized control } \\
\text { trial. No language } \\
\text { restrictions. } \\
\text { Considered } \\
\text { intervention } \\
\text { activity scheduling } \\
\text { when registration } \\
\text { of pleasant } \\
\text { activities and the } \\
\text { increase of positive } \\
\text { interactions } \\
\text { between a person } \\
\text { and his/her } \\
\text { environment were } \\
\text { the core elements } \\
\text { of the treatment. } \\
\text { Methodological } \\
\text { quality of the } \\
\text { studies was } \\
\text { assessed using } 4 \\
\text { criteria by Higgins } \\
\& \text { Green (2005). } \\
\text { Calculated effect } \\
\text { sizes using only } \\
\text { instruments from } \\
\text { studies that } \\
\text { explicitly measure }\end{array}$ & $\begin{array}{l}16 \text { studies with a } \\
\text { total of } 780 \\
\text { subjects met } \\
\text { inclusion criteria } \\
\text { and were } \\
\text { included. }\end{array}$ & $\begin{array}{l}\text { Mean effect size } \\
\text { between activity } \\
\text { scheduling and } \\
\text { control condition } \\
\text { indicating a large } \\
\text { effect favoring } \\
\text { activity scheduling. } \\
\text { The pooled effect } \\
\text { size between activity } \\
\text { scheduling and other } \\
\text { psychological } \\
\text { treatments was } 0.13 \\
\text { indicating a small } \\
\text { effect favoring } \\
\text { activity scheduling } \\
\text { without significant } \\
\text { difference. } \\
\text { The pooled effect } \\
\text { size between activity } \\
\text { scheduling and } \\
\text { cognitive therapy } \\
\text { was } 0.02 \text { indicating a } \\
\text { small effect favoring } \\
\text { activity scheduling. } \\
\text { The pooled effect } \\
\text { size between activity } \\
\text { scheduling and } \\
\text { CT+AS was - } 0.01 \\
\text { indicating a small } \\
\text { effect favoring } \\
\text { CT+AS. } \\
\text { The pooled effect } \\
\text { size between CT and } \\
\text { a combination of } \\
\text { CT+AS was - } 0.16 \\
\text { indicating a small } \\
\text { effect favoring } \\
\text { CT+AS. } \\
\text { The effect size } \\
\text { between activity } \\
\text { scheduling and } \\
\text { antidepressant } \\
\text { medication was } 0.26 \\
\text { indicating a small } \\
\text { effect in favor of } \\
\text { activity scheduling. } \\
\text { to a control condition } \\
\text { at follow-up ranged } \\
\text { from } 0.88 \text { at two } \\
\text { months to } 0.54 \text { at six } \\
\text { months indicating a } \\
\text { large and moderate }\end{array}$ & $\begin{array}{l}\text { Authors } \\
\text { found clear } \\
\text { indications } \\
\text { that activity } \\
\text { scheduling is } \\
\text { effective in } \\
\text { the } \\
\text { treatment of } \\
\text { depression in } \\
\text { adults. The } \\
\text { overall effect } \\
\text { size of } 0.87 \text { is } \\
\text { large and } \\
\text { comparable } \\
\text { to effect sizes } \\
\text { found for } \\
\text { other } \\
\text { psychological } \\
\text { treatments } \\
\text { and } \\
\text { treatments } \\
\text { with } \\
\text { antidepressa } \\
\text { nts. Several } \\
\text { studies } \\
\text { compared AS } \\
\text { to CT and } \\
\text { indicated that } \\
\text { AS and CT are } \\
\text { equally } \\
\text { effective } \\
\text { including at } \\
\text { follow-up } \\
\text { periods up to } \\
6 \text { months. }\end{array}$ & \\
\hline
\end{tabular}




\begin{tabular}{|c|c|c|c|c|c|}
\hline & & $\begin{array}{l}\text { depression. To } \\
\text { calculate pooled } \\
\text { mean effect sizes, } \\
\text { the computer } \\
\text { program } \\
\text { Comprehensive } \\
\text { Meta-analysis was } \\
\text { developed. } \\
\text { Cochran's } \\
\text { heterogeneity } \\
\text { statistic. }\end{array}$ & & $\begin{array}{l}\text { effect respectively } \\
\text { suggesting some } \\
\text { support for the } \\
\text { effectiveness of } \\
\text { activity scheduling in } \\
\text { the long-term. } \\
\text { The pooled effect } \\
\text { size was } 0.18 \\
\text { indicating a small but } \\
\text { nonsignificant } \\
\text { improvement from } \\
\text { post-test to follow- } \\
\text { up. The change } \\
\text { between post-test } \\
\text { and } 4-6 \text { months } \\
\text { follow-up resulted in } \\
\text { a pooled effect size } \\
\text { of } 0.03 \text { indicating a } \\
\text { small effect. The } \\
\text { change from post- } \\
\text { test to } 7-12 \text { months } \\
\text { follow-up was } 0.53 \text {, } \\
\text { indicating a } \\
\text { moderate effect. } \\
\text { Effects of activity } \\
\text { scheduling at follow- } \\
\text { up could be } \\
\text { compared to the } \\
\text { effects of CT at } 1-2 \\
\text { months with a } \\
\text { pooled effect size of } \\
0.02 \text {. Effects of } \\
\text { activity scheduling at } \\
\text { follow-up compared } \\
\text { to CT at follow-up at } \\
4-6 \text { months had a } \\
\text { pooled effect size of - } \\
0.13 \text { indicating } \\
\text { nonsignificant } \\
\text { differences between } \\
\text { CT and activity } \\
\text { scheduling at follow- } \\
\text { up. CT vs. activity } \\
\text { scheduling at one } \\
\text { year follow-up d = } \\
0.30 \text {. }\end{array}$ & \\
\hline $\begin{array}{l}\text { Dimidjian, S., } \\
\text { Hollon, S.D., } \\
\text { Dobson, K.S., } \\
\text { Schmaling, } \\
\text { K.B., } \\
\text { Kohlenberg, } \\
\text { R.J., Addis, } \\
\text { M.E., Gallop, } \\
\text { R., } \\
\text { McGlinchey, } \\
\text { J.B., Markley, } \\
\text { D.K., Gollan, } \\
\text { J.K., Atkins, } \\
\text { D.C., Dunner, } \\
\text { D.L., \& } \\
\text { Jacobson, N.S. } \\
\text { (2006). }\end{array}$ & $\begin{array}{l}\text { To test the relative } \\
\text { efficacy of BA in } \\
\text { acute treatment of } \\
\text { major depression by } \\
\text { comparing it both } \\
\text { with CT alone and } \\
\text { with ADM in the } \\
\text { context of a placebo- } \\
\text { controlled trial; to } \\
\text { test whether either } \\
\text { psychosocial } \\
\text { treatment was a } \\
\text { viable alternative to } \\
\text { ADM in the } \\
\text { treatment of } \\
\text { moderate to severe } \\
\text { depression. } \\
\text { Treatments included }\end{array}$ & $\begin{array}{l}\text { Randomized } \\
\text { control trial. } \\
\text { Eligible participants } \\
\text { were randomly } \\
\text { assigned to a } \\
\text { treatment using a } \\
\text { computer- } \\
\text { generated } \\
\text { randomization list } \\
\text { consisting of BA, } \\
\text { CT, ADM, or PLA. } \\
\text { Depression severity } \\
\text { was used as } \\
\text { stratification } \\
\text { variable during } \\
\text { randomization. } \\
\text { Scores on } \\
\text { pretreatment HRSD }\end{array}$ & $\begin{array}{l}\text { Participants } \\
\text { consisted of } 241 \\
\text { individuals } \\
\text { between ages of } \\
18 \text { and } 60 \text { years } \\
\text { who met criteria } \\
\text { for major } \\
\text { depression } \\
\text { according to the } \\
\text { DSM-IV and } \\
\text { scored } 20 \text { or } \\
\text { higher on BDI-II } \\
\text { and } 14 \text { of greater } \\
\text { on the } 17 \text {-item } \\
\text { Hamilton Rating } \\
\text { Scale for } \\
\text { Depression. } \\
\text { Recruitment }\end{array}$ & $\begin{array}{l}\text { In high-severity } \\
\text { subgroup, significant } \\
\text { overall improvement } \\
\text { by time for all groups } \\
\text { on the BDI and on } \\
\text { evaluator rated } \\
\text { HRSD, } p<0.0001 . \\
\text { Participants in BA } \\
\text { improved } \\
\text { significantly more per } \\
\text { treatment than in } C T \\
\text { on both } B D \text { I } \\
\text { ( } p=0.029 \text { ), and the } \\
\text { HRSD ( } p=0.038 \text { ). } \\
\text { Participants in ADM } \\
\text { improved } \\
\text { significantly more per } \\
\text { treatment than in CT }\end{array}$ & $\begin{array}{l}\text { Results of this } \\
\text { study indicate } \\
\text { that BA is } \\
\text { comparable } \\
\text { in efficacy to } \\
\text { ADM and } \\
\text { more } \\
\text { efficacious } \\
\text { than CT } \\
\text { among more } \\
\text { severely } \\
\text { depressed } \\
\text { patients. } \\
\text { Results also } \\
\text { provide } \\
\text { further } \\
\text { confirmation } \\
\text { of }\end{array}$ \\
\hline
\end{tabular}




\begin{tabular}{|c|c|c|c|c|c|}
\hline & $\begin{array}{l}\text { BA, CT, } \\
\text { antidepressant } \\
\text { medication (ADM) or } \\
\text { pill placebo (PLA). } \\
\text { Measures included } \\
\text { diagnosis, } \\
\text { depression severity, } \\
\text { adherence and } \\
\text { competence, } \\
\text { response and } \\
\text { remission. }\end{array}$ & $\begin{array}{l}\text { were used to form } \\
\text { two groups of high } \\
\text { or low severity. } \\
\text { Participants were } \\
\text { assigned to } \\
\text { therapists within } \\
\text { modality based on } \\
\text { therapist } \\
\text { availability. BA } \\
\text { condition received } \\
\text { max of } 24,50 \text {-min } \\
\text { sessions over } 16 \\
\text { weeks, generally } \\
\text { held twice weekly } \\
\text { for first } 8 \text { weeks } \\
\text { and once weekly } \\
\text { for second } 8 \\
\text { weeks. CT } \\
\text { condition followed } \\
\text { the same protocol } \\
\text { regarding } \\
\text { frequency, } \\
\text { schedule, and } \\
\text { allotment of } \\
\text { treatment sessions } \\
\text { as the BA } \\
\text { condition. Both } \\
\text { ADM and PLA } \\
\text { conditions were } \\
\text { administered in a } \\
\text { triple-blind manner } \\
\text { during first } 8 \text { weeks } \\
\text { then the blind was } \\
\text { broken and PLA } \\
\text { participants were } \\
\text { offered their choice } \\
\text { of treatment at } \\
\text { study expense. } \\
\text { ADM was } \\
\text { administered in a } \\
\text { single-blind } \\
\text { manner for the } \\
\text { final } 8 \text { weeks. } \\
\text { Participants were } \\
\text { seen weekly for the } \\
\text { first } 4 \text { weeks and } \\
\text { biweekly thereafter } \\
\text { through week } 16 \\
\text { (although PLA were } \\
\text { terminated at week } \\
\text { 8). First } \\
\text { pharmacotherapy } \\
\text { session was } 30-45 \\
\text { min and } \\
\text { subsequent } \\
\text { sessions lasted up } \\
\text { to } 30 \text { minutes. } \\
\text { Diagnosis was } \\
\text { measured using a } \\
\text { standardized } \\
\text { clinical interview, } \\
\text { depression severity } \\
\text { was measured } \\
\text { using a modified } \\
\text { 17-item version of } \\
\text { the HRSD and the }\end{array}$ & $\begin{array}{l}\text { occurred } \\
\text { between } 1998 \\
\text { and } 2001 \text { from } \\
\text { media } \\
\text { advertisements, } \\
\text { referral from } \\
\text { local agencies, } \\
\text { and word of } \\
\text { mouth or } \\
\text { referral. } \\
\text { Participants were } \\
\text { excluded if they } \\
\text { had a dx of } \\
\text { psychosis or } \\
\text { bipolar dx, } \\
\text { organic brain } \\
\text { syndrome, } \\
\text { mental } \\
\text { retardation, } \\
\text { substantial and } \\
\text { imminent suicide } \\
\text { risk, current or } \\
\text { primary diagnosis } \\
\text { of alcohol or durg } \\
\text { abuse panic } \\
\text { disorder, } \\
\text { obsessive- } \\
\text { compulsive } \\
\text { disorder, } \\
\text { psychogenic pain } \\
\text { disorder, } \\
\text { anorexia, or } \\
\text { bulimia, presence } \\
\text { of antisocial, } \\
\text { borderline, or } \\
\text { schizotypal } \\
\text { personality } \\
\text { disorder, or } \\
\text { nonresponse to } \\
\text { adequate trial of } \\
\text { CT or paroxetine } \\
\text { within the } \\
\text { previous year. }\end{array}$ & $\begin{array}{l}\text { on both BDI } \\
\text { ( } p=0.007 \text { ) and HRSD } \\
\text { ( } \mathrm{p}-0.022 \text { ). No sig diff } \\
\text { in the rate of } \\
\text { improvements } \\
\text { between BA and } \\
\text { ADM on BDI or HRSD } \\
\text { ( } \mathrm{p}=0.80, \mathrm{p}=0.96 \text { ). } \\
\text { Using the BDI and } \\
\text { HRSD, ADM and BA } \\
\text { lie within the margin } \\
\text { of noninferiority, } \\
\text { with a probability } \\
\text { larger than } 99.1 \% \text {. } \\
\text { In low-severity } \\
\text { subgroup, there was } \\
\text { significant overall } \\
\text { improvement by time } \\
\text { for all groups on the } \\
\text { BDI ( } p<0.0001 \text { ) and } \\
\text { the HRSD ( } \mathrm{p}<0.0001 \text { ). } \\
\text { No evidence of } \\
\text { differential } \\
\text { improvement over } \\
\text { time by treatment on } \\
\text { BDI or HRSD. } \\
\text { Among more } \\
\text { severely depressed } \\
\text { patients, overall } \\
\text { combined rates of } \\
\text { response and } \\
\text { remission based on } \\
\text { the BDI were } 48 \% \text { in } \\
C T, 76 \% \text { in BA, and } \\
49 \% \text { in ADM. On the } \\
\text { basis of HRSD overall } \\
\text { rates were } 56 \% \text { in } C T \text {, } \\
60 \% \text { in BA, and } 40 \% \\
\text { in ADM. Significantly } \\
\text { greater percentage of } \\
\text { BA participants met } \\
\text { BDI response criteria } \\
\text { compared with } \\
\text { receiving CT } \\
\text { ( } p=0.048 \text { ). Rates of } \\
\text { remission high- } \\
\text { severity subgroup } \\
\text { based on BDI were } \\
40 \% \text { in CT, } 52 \% \text { in BA, } \\
\text { and } 42 \% \text { in ADM. On } \\
\text { basis of HRSD, overall } \\
\text { rates of remission } \\
\text { were } 36 \% \text { in CT, } 56 \% \\
\text { in BA, and } 23 \% \text { in } \\
\text { ADM. No signitts indicents on BDI. } \\
\text { significant } \\
\text { differences between } \\
\text { treatments on the } \\
\text { HRSD ( } p=0.012 \text { ) with } \\
\text { a significantly greater } \\
\text { percentage of BA } \\
\text { participants reaching }\end{array}$ & $\begin{array}{l}\text { importance } \\
\text { of initial } \\
\text { severity in } \\
\text { analysis of } \\
\text { treatment } \\
\text { outcome } \\
\text { because } \\
\text { differential } \\
\text { treatment } \\
\text { effects were } \\
\text { observed } \\
\text { only among } \\
\text { those } \\
\text { patients who } \\
\text { were more } \\
\text { severely } \\
\text { depressed. } \\
\text { For more } \\
\text { severely } \\
\text { depressed } \\
\text { patients BA } \\
\text { and ADM } \\
\text { were } \\
\text { comparable } \\
\text { on self-report } \\
\text { and clinical } \\
\text { ratings and } \\
\text { BA brought a } \\
\text { significantly } \\
\text { greater } \\
\text { percentage of } \\
\text { participants } \\
\text { to remission } \\
\text { and retained } \\
\text { a great } \\
\text { percentage of } \\
\text { participants } \\
\text { in in } \\
\text { treatment. } \\
\text { Results } \\
\text { underscore } \\
\text { the value of } \\
\text { sustained use } \\
\text { of simple } \\
\text { behavioral } \\
\text { strategies, } \\
\text { depreatment of } \\
\text { such as goal } \\
\text { particularling, self- } \\
\text { well in this } \\
\text { study. It was } \\
\text { at least as } \\
\text { activity- } \\
\text { scheducing, } \\
\text { pDM, eveus as } \\
\text { problem- } \\
\text { amolving, and } \\
\text { graded task } \\
\text { assignment in } \\
\text { the more }\end{array}$ \\
\hline
\end{tabular}




\begin{tabular}{|c|c|c|c|c|c|}
\hline & & $\begin{array}{l}\text { BDI-II. HRSD was } \\
\text { administered at } \\
\text { pre-, mid-, and } \\
\text { post-treatment and } \\
\text { as required. HRSD } \\
\text { was administered } \\
\text { at each session } \\
\text { during the first } 8 \\
\text { weeks for ADM and } \\
\text { PLA participants. } \\
\text { BDI-II was } \\
\text { administered at } \\
\text { pre-, mid-, and } \\
\text { post-treatment and } \\
\text { as required. } \\
\text { Treatment } \\
\text { adherence was } \\
\text { measured using a } \\
\text { version of the } \\
\text { Collaborative Study } \\
\text { Psychotherapy } \\
\text { Rating Scale } \\
\text { modified to } \\
\text { accommodate } \\
\text { inclusion of BA, and } \\
\text { Cognitive Therapy } \\
\text { Scale for } \\
\text { competence of CT } \\
\text { delivery. Response } \\
\text { is significant } \\
\text { symptomatic } \\
\text { improvement and } \\
\text { remission is } \\
\text { improvement to } \\
\text { the point of being } \\
\text { asymptomatic } \\
\text { within normal } \\
\text { range. On HRSD } \\
\text { and BDI, response } \\
\text { was defined as at } \\
\text { least } 50 \% \text { reduction } \\
\text { from baseline and } \\
\text { remission was } \\
\text { defined as scores } \\
\text { less than or equal } \\
\text { to } 7 \text { on HRSD and } \\
\text { 10 on the BDI. }\end{array}$ & & $\begin{array}{l}\text { remission as } \\
\text { compared with ADM. } \\
\text { Among less severely } \\
\text { depressed, overall } \\
\text { rates of response } \\
\text { based on BDI were } \\
65 \% \text { in } C T, 50 \% \text { in BA, } \\
\text { and } 56 \% \text { in ADM. On } \\
\text { basis of HRSD overall } \\
\text { response rates were } \\
60 \% \text { in CT, 39\% in BA, } \\
\text { and } 47 \% \text { in ADM. No } \\
\text { significant } \\
\text { differences between } \\
\text { treatments on BDI. } \\
\text { Rates of remission } \\
\text { based on BDI were } \\
55 \% \text { in CT, } 44 \% \text { in BA, } \\
\text { and } 42 \% \text { in ADM. On } \\
\text { basis of HRSD overall } \\
\text { rates of remission } \\
\text { were } 50 \% \text { in CT, 39\% } \\
\text { in BA, and } 33 \% \text { in } \\
\text { ADM. No significant } \\
\text { difference between } \\
\text { treatments on BDI or } \\
\text { HRSD. }\end{array}$ & $\begin{array}{l}\text { severely } \\
\text { depressed } \\
\text { participants, } \\
\text { and retained } \\
\text { a greater } \\
\text { proportion of } \\
\text { patients long } \\
\text { enough for } \\
\text { them to } \\
\text { benefit from } \\
\text { treatment. } \\
\text { BA was also } \\
\text { more } \\
\text { efficacious } \\
\text { than CT } \\
\text { among more } \\
\text { severely } \\
\text { depressed } \\
\text { participants. } \\
\text { Interest in BA } \\
\text { was based in } \\
\text { part on the } \\
\text { notion that it } \\
\text { would be a } \\
\text { more } \\
\text { exportable } \\
\text { treatment } \\
\text { that is easier } \\
\text { to implement } \\
\text { and train } \\
\text { than CT or } \\
\text { other more } \\
\text { complex } \\
\text { interventions. }\end{array}$ \\
\hline $\begin{array}{l}\text { Dobson, K.S., } \\
\text { Hollon, S.D., } \\
\text { Dimidjian, S., } \\
\text { Schmaling, } \\
\text { K.B., } \\
\text { Kohlenberg, } \\
\text { R.J., Gallop, } \\
\text { R.J., Rizvi, S.L., } \\
\text { Gollan, J.K., } \\
\text { Dunner, D.L., } \\
\text { \& Jacobson, } \\
\text { N.S. (2008). }\end{array}$ & $\begin{array}{l}\text { To determine } \\
\text { enduring effects of } \\
\text { prior exposure to BA, } \\
\text { prior exposure to CT, } \\
\text { and continued } \\
\text { treatment with ADM } \\
\text { in the context of a } \\
\text { placebo-controlled } \\
\text { trial. To determine } \\
\text { whether effects of } \\
\text { prior psychosocial } \\
\text { treatments extended } \\
\text { beyond the } \\
\text { prevention of } \\
\text { relapse to the } \\
\text { prevention of } \\
\text { recurrence during a } \\
2^{\text {nd }} \text { year follow-up } \\
\text { after acute }\end{array}$ & $\begin{array}{l}\text { Participants were } \\
\text { recruited from the } \\
\text { original Dimidjian } \\
\text { (2006) study and } \\
\text { consisted of } 106 \\
\text { patients who had } \\
\text { been assigned to } \\
\text { active treatment } \\
\text { but no longer met } \\
\text { the diagnostic } \\
\text { criteria for MDD at } \\
\text { the end of the } \\
\text { acute phase of } \\
\text { treatment. Data } \\
\text { were available to } \\
\text { estimate risk to the } \\
\text { point of relapse or } \\
\text { recurrence for } 92 \\
\text { of the } 106 \text { patients }\end{array}$ & $\begin{array}{l}\text { Participants were } \\
\text { followed to the } \\
\text { point of relapse } \\
\text { or recurrence for } \\
\text { up to } 2 \text { years } \\
\text { following } \\
\text { response to } \\
\text { acute treatment. } \\
1^{\text {st }} \text { year } \\
\text { compared prior } \\
\text { CT, BA, and ADM. } \\
\text { Participants who } \\
\text { had received } \\
\text { ADM were } \\
\text { randomized by } \\
\text { previous } \\
\text { assignment and } \\
\text { continued active } \\
\text { medication or }\end{array}$ & $\begin{array}{l}\text { Relapse: Especially } \\
\text { likely to occur at the } \\
\text { start of the } 1^{\text {st }} \text { follow- } \\
\text { up year, especially } \\
\text { for medication } \\
\text { responders } \\
\text { withdrawn onto } \\
\text { placebo (cPLA). Rates } \\
\text { of relapse during } 1^{\text {st }} \\
\text { follow-up year were } \\
39 \% \text { for prior CT, 50\% } \\
\text { for prior BA, } 53 \% \text { for } \\
\text { cADM, and } 59 \% \text { for } \\
\text { cPLA. Active } \\
\text { treatments were } \\
\text { superior to } \\
\text { withdrawal onto } \\
\text { placebo ( } p=0.04 \text { ). } \\
\text { Separately prior CT }\end{array}$ & $\begin{array}{l}\text { Overall } \\
\text { pattern of } \\
\text { results } \\
\text { observed } \\
\text { indicates that } \\
\text { prior } \\
\text { treatment } \\
\text { with either } \\
\text { CT or BA has } \\
\text { an enduring } \\
\text { effect that is } \\
\text { at least as } \\
\text { efficacious as } \\
\text { continuing } \\
\text { patients on } \\
\text { medication } \\
\text { and that held } \\
\text { for the } \\
\text { prevention of }\end{array}$ \\
\hline
\end{tabular}




\begin{tabular}{|c|c|c|c|c|c|}
\hline & $\begin{array}{l}\text { treatment. Outcome } \\
\text { measures included } \\
\text { relapse and } \\
\text { recurrence. Relapse } \\
\text { is defined as the } \\
\text { return of the treated } \\
\text { episode of } \\
\text { depression, and in } \\
\text { this study as either } \\
\text { HRSD scores of } 14 \text { or } \\
\text { greater or PSRs of } 5 \\
\text { or greater for } 2 \\
\text { successive weeks } \\
\text { during the } 1^{\text {st }} \text { year of } \\
\text { follow-up. } \\
\text { Recurrence is } \\
\text { defined as the onset } \\
\text { of a new episode of } \\
\text { depression, and in } \\
\text { this study as either } \\
\text { HRSD scores of } 14 \text { or } \\
\text { greater or PSRs of } 5 \\
\text { or greater for } 2 \\
\text { successive weeks } \\
\text { during the } 2^{\text {nd }} \text { year of } \\
\text { follow-up. }\end{array}$ & $\begin{array}{l}\text { who entered } \\
\text { follow-up period. }\end{array}$ & 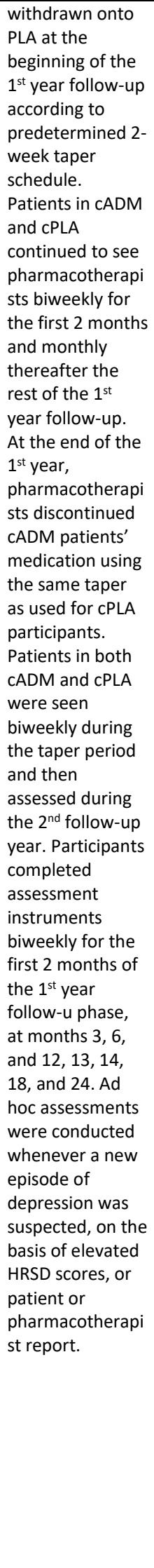 & $\begin{array}{l}\text { was significantly } \\
\text { superior to cPLA ( } p= \\
0.02 \text { ) and prior BA } \\
\text { demonstrated a } \\
\text { nonsignificant trend } \\
\text { ( } p=0.09 \text { ), but cADM } \\
\text { was not significantly } \\
\text { different from cPLA } \\
\text { ( } p=0.33 \text { ). Prior } \\
\text { exposure to CT } \\
\text { reduced risk for } \\
\text { relapse by } 64 \% \\
\text { relative to } \\
\text { medication } \\
\text { withdrawal. cADM } \\
\text { reduced risk for } \\
\text { relapse by about } \\
33 \% \text {. Prior exposure } \\
\text { to BA was associated } \\
\text { with a reduction in } \\
\text { risk for relapse by } \\
51 \% \text {, and is } \\
\text { comparable to the } \\
\text { effect typically } \\
\text { observed for } \\
\text { continuation of } \\
\text { medication. } \\
\text { Recurrence: Patients } \\
\text { in cADM were } \\
\text { withdrawn from } \\
\text { medication at the } \\
\text { beginning of } 2^{\text {nd }} \text { year } \\
\text { follow-up. Rates of } \\
\text { recurrence during } 2^{\text {nd }} \\
\text { follow-up year were } \\
24 \% \text { for prior } C T, 26 \% \\
\text { for prior BA, and } 52 \% \\
\text { for prior } c A D M . \\
\text { Effect of prior } C T \text { and } \\
\text { BA showed a } \\
\text { nonsignificant trend } \\
\text { compared to the } \\
\text { effect of prior } c A D M \\
\text { ( } p=0.06 \text { ). Prior } \\
\text { exposure to either } C T \\
\text { or BA reduced the } \\
\text { risk of recurrence by } \\
\text { about } 63 \% \text { relative to } \\
\text { medication } \\
\text { withdrawal. The } \\
\text { overall effect for } \\
\text { treatment was } \\
\text { significant ( } p=0.04 \text { ) } \\
\text { with both prior CT } \\
\text { and BA being } \\
\text { superior to } \\
\text { continuation of } \\
\text { medication followed } \\
\text { by medication } \\
\text { withdrawal. Prior CT } \\
\text { was significantly } \\
\text { superior to cADM ( } p \\
=0.02 \text { ) whereas prior } \\
\text { BA exhibited a } \\
\text { nonsignificant trend } \\
\text { in the same direction }\end{array}$ & $\begin{array}{l}\text { relapse and } \\
\text { possibly } \\
\text { recurrence. } \\
\text { Evidence for } \\
\text { enduring } \\
\text { effect was } \\
\text { clearer for } \\
\text { prior CT than } \\
\text { BA but } \\
\text { differences } \\
\text { between two } \\
\text { psychosocial } \\
\text { interventions } \\
\text { never } \\
\text { approached } \\
\text { statistical } \\
\text { significance } \\
\text { and were } \\
\text { relatively } \\
\text { small in } \\
\text { magnitude. } \\
\text { The } \\
\text { indication } \\
\text { that BA may } \\
\text { also have an } \\
\text { enduring } \\
\text { effect } \\
\text { comparable } \\
\text { to CT, but not } \\
\text { for patients } \\
\text { successfully } \\
\text { treated with } \\
\text { medication, is } \\
\text { particularly } \\
\text { noteworthy. } \\
\text { Because } \\
\text { behavioral } \\
\text { ideas are } \\
\text { used } \\
\text { repeatedly } \\
\text { during acute } \\
\text { treatment, } \\
\text { they are } \\
\text { highly salient } \\
\text { and thus } \\
\text { recall is } \\
\text { increased at } \\
\text { times of } \\
\text { potential } \\
\text { relapse. BA is } \\
\text { implemented } \\
\text { in a manner } \\
\text { that is } \\
\text { intended to } \\
\text { both teach } \\
\text { coping skills } \\
\text { and reduce } \\
\text { further risk. } \\
\text { Although } \\
\text { antidepressa } \\
\text { nt } \\
\text { medications } \\
\text { generally are } \\
\text { safe and } \\
\text { efficacious, } \\
\text { there is little }\end{array}$ \\
\hline
\end{tabular}




\begin{tabular}{|c|c|c|c|c|c|}
\hline & & & & $\begin{array}{l}\text { ( } p=0.08) \text {. Prior } \\
\text { exposure to BA was } \\
\text { associated with a } \\
\text { reduction in risk of } \\
47 \% \text { relative to cADM } \\
\text { and prior CT was } \\
\text { associated with a } \\
\text { reduction in risk of } \\
58 \% \text {. CT and BA were } \\
\text { directly compared } \\
\text { with maximal power } \\
\text { provided by full 2- } \\
\text { year comparison and } \\
\text { did not significantly } \\
\text { differ ( } p=0.57) \text {. CT } \\
\text { was associated with a } \\
\text { reduction in risk of } \\
27 \% \text { relative to prior } \\
\text { BA. Over one third of } \\
\text { patients initially } \\
\text { assigned to BA/CT } \\
\text { showed sustained } \\
\text { outcomes across the } \\
\text { course of acute } \\
\text { treatment and the } 1^{\text {st }} \\
\text { follow-up year, } \\
\text { compared to less } \\
\text { than a quarter of the } \\
\text { patients initially } \\
\text { assigned to } \\
\text { pharmacotherapy. } \\
\text { Comparisons } \\
\text { revealed that only } \\
\text { prior CT had a } \\
\text { greater sustained } \\
\text { response than both } \\
\text { cADM. Across the } 2^{\text {nd }} \\
\text { follow-up year, rats } \\
\text { of sustained recovery } \\
\text { were } 35 \% \text { for prior } \\
C T \text { and } 28 \% \text { for prior } \\
\text { BA. This indicates } \\
\text { that brief treatment } \\
\text { with either CT or BA } \\
\text { is as efficacious over } \\
\text { the long run as } \\
\text { keeping people on } \\
\text { ADM. }\end{array}$ & $\begin{array}{l}\text { evidence that } \\
\text { they alter the } \\
\text { course of the } \\
\text { disorder. } \\
\text { Because } \\
\text { depression is } \\
\text { often chronic } \\
\text { or recurrent, } \\
\text { any } \\
\text { treatment } \\
\text { with an } \\
\text { enduring } \\
\text { effect is } \\
\text { particularly } \\
\text { worthwhile. } \\
\text { Even though } \\
\text { little } \\
\text { evidence was } \\
\text { found of a } \\
\text { preventive } \\
\text { effect for the } \\
\text { continuation } \\
\text { of } \\
\text { medication, it } \\
\text { was striking } \\
\text { how rapidly } \\
\text { even } \\
\text { recovered } \\
\text { patients } \\
\text { experienced } \\
\text { a recurrence } \\
\text { when } \\
\text { medication } \\
\text { was } \\
\text { withdrawn. } \\
\text { Overall, } \\
\text { current } \\
\text { results } \\
\text { suggest that } \\
\text { BA may have } \\
\text { an enduring } \\
\text { effect similar } \\
\text { to that } \\
\text { produced by } \\
\text { CT. Prior CT } \\
\text { was superior } \\
\text { to medication } \\
\text { withdrawal, } \\
\text { and prior BA } \\
\text { did almost as } \\
\text { well (at a } \\
\text { nonsignifican } \\
\text { was at least } \\
\text { as effective } \\
\text { as continued } \\
\text { medication. }\end{array}$ \\
\hline $\begin{array}{l}\text { Ekers, D., } \\
\text { Richards, D., \& } \\
\text { Gilbody, S. } \\
\text { (2007). }\end{array}$ & $\begin{array}{l}\text { To compare } \\
\text { behavioural } \\
\text { interventions for } \\
\text { depression to other } \\
\text { psychological } \\
\text { approaches and } \\
\text { controls. }\end{array}$ & $\begin{array}{l}\text { Meta-analysis. } \\
\text { Database search } \\
\text { from inception to } \\
\text { January } 2006 \\
\text { (including Medline, } \\
\text { EMBASE, PsycINFO, } \\
\text { Cochrane Library } \\
\text { DARE, CINAHL, } \\
\text { AMED, and British }\end{array}$ & $\begin{array}{l}20 \text { studies, } 1109 \\
\text { subjects } \\
\text { BT vs waiting } \\
\text { list/control/place } \\
\text { bo: } 12 \text { studies, } \\
459 \text { participants } \\
\text { from adult } \\
\text { community }\end{array}$ & $\begin{array}{l}\text { BT vs. Waiting } \\
\text { list/placebo/control: } \\
\text { Large effect with a } \\
\text { pooled SMD } \\
\text { demonstrating highly } \\
\text { significant difference } \\
\text { in symptom level } \\
\text { scores favoring BT ( } p \\
<0.001 \text { ). Average }\end{array}$ & $\begin{array}{l}\text { Data showed } \\
\text { clear } \\
\text { evidence that } \\
\text { BT is an } \\
\text { effective } \\
\text { treatment for } \\
\text { depression } \\
\text { and provides } \\
\text { superior }\end{array}$ \\
\hline
\end{tabular}




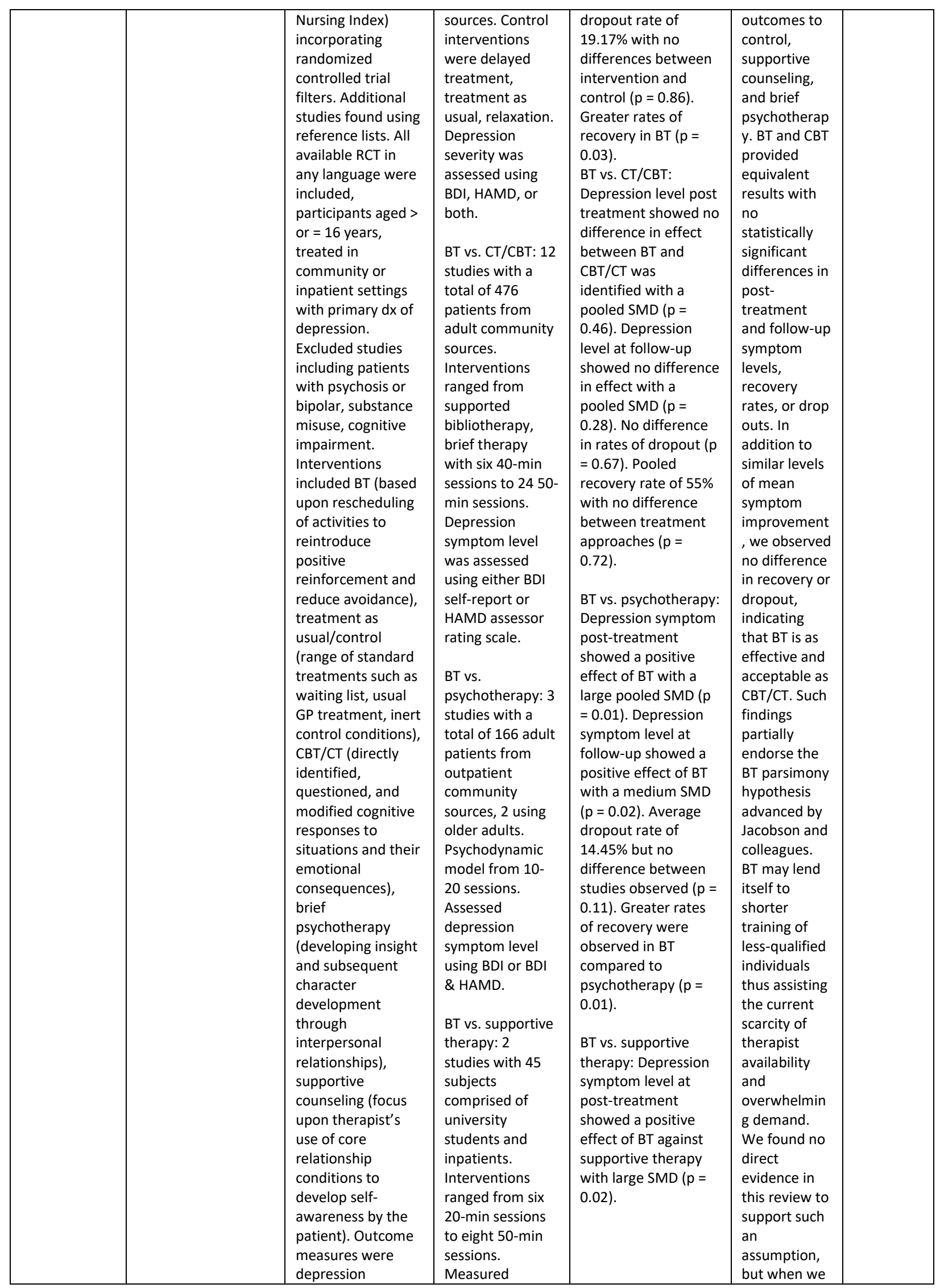




\begin{tabular}{|c|c|c|c|c|c|}
\hline & & $\begin{array}{l}\text { symptom-level self- } \\
\text { rated (BDI) or } \\
\text { clinician rated } \\
\text { (HAMD), and } \\
\text { recovery and } \\
\text { dropout rates were } \\
\text { entered as } \\
\text { dichotomous data. } \\
\text { Quality } \\
\text { assessment, data } \\
\text { extraction and } \\
\text { synthesis (data } \\
\text { from each trial at } \\
\text { post-treatment and } \\
\text { follow-up of } 6 \\
\text { months or nearest } \\
\text { available data } \\
\text { synthesized using } \\
\text { Cochrane } \\
\text { collaboration } \\
\text { RevMan program), } \\
\text { data pooling, } \\
\text { exploration of } \\
\text { heterogeneity. }\end{array}$ & $\begin{array}{l}\text { depression } \\
\text { symptom levels } \\
\text { by self-report BDI } \\
\text { and HAMD. }\end{array}$ & & $\begin{array}{l}\text { examined the } \\
\text { impact on } \\
\text { level of } \\
\text { training of } \\
\text { those who } \\
\text { had delivered } \\
\text { BT in meta- } \\
\text { regression, } \\
\text { we did not } \\
\text { find that } \\
\text { superior } \\
\text { outcomes } \\
\text { were } \\
\text { associated } \\
\text { with 'higher' } \\
\text { level } \\
\text { qualifications. } \\
\text { In summary, } \\
\text { BT for } \\
\text { depression is } \\
\text { an effective } \\
\text { intervention } \\
\text { that has } \\
\text { equal, if not } \\
\text { better, } \\
\text { outcomes } \\
\text { than } \\
\text { alternative } \\
\text { and currently } \\
\text { recommende } \\
\text { d therapies. }\end{array}$ \\
\hline $\begin{array}{l}\text { Funderburk, } \\
\text { J.S., Pigeon, } \\
\text { W.R., } \\
\text { Shepardson, } \\
\text { R.L., \& Maisto, } \\
\text { S.A. (2019). }\end{array}$ & $\begin{array}{l}\text { To address the need } \\
\text { for brief depression } \\
\text { treatments in } \\
\text { primary care. } \\
\text { Intervention variable } \\
\text { was brief behavioral } \\
\text { activation } \\
\text { intervention, } \\
\text { measured variables } \\
\text { were patient } \\
\text { engagement, } \\
\text { satisfaction, } \\
\text { acceptability, } \\
\text { treatment response, } \\
\text { and fidelity. }\end{array}$ & $\begin{array}{l}\text { Pre-test/post-test } \\
\text { design without } \\
\text { randomization or } \\
\text { control. Open trial. } \\
\text { Eligible patients } \\
\text { completed a } \\
\text { baseline } \\
\text { assessment and } \\
\text { follow-up } \\
\text { assessment at } 12 \\
\text { weeks. Participants } \\
\text { received two } \\
\text { appointments of } \\
\text { BA-PC with two } \\
\text { boosters spaced 2- } \\
3 \text { weeks apart. } \\
\text { Content was } \\
\text { modified from the } \\
\text { original 10- } \\
\text { appointment brief } \\
\text { BA treatment } \\
\text { manual for } \\
\text { depression. } \\
\text { Booster appts did } \\
\text { not introduce new } \\
\text { content, but } \\
\text { reviewed material } \\
\text { from previous } \\
\text { appts, problem } \\
\text { solved barriers, and } \\
\text { set new goals. }\end{array}$ & $\begin{array}{l}\text { Participants were } \\
\text { recruited from } \\
\text { two VHA primary } \\
\text { care clinics. } \\
\text { Patients who } \\
\text { screened positive } \\
\text { on PHQ-2 in the } \\
\text { previous month } \\
\text { were identified } \\
\text { by EMR and } \\
\text { contacted via } \\
\text { mail and } \\
\text { telephone. These } \\
\text { patients were } \\
\text { eligible if they } \\
\text { met criteria } \\
\text { including: } \\
\text { depressive } \\
\text { symptoms of at } \\
\text { least moderate } \\
\text { severity termed } \\
\text { PHQ-9 > or = 10, } \\
\text { no current mania } \\
\text { or psychosis, no } \\
\text { current dx of } \\
\text { bipolar, no } \\
\text { psychotherapy } \\
\text { for depressive } \\
\text { symptoms within } \\
\text { the past month, } \\
\text { no } \\
\text { antidepressants } \\
\text { or on stable dose } \\
>3 \text { months, no } \\
\text { engagement in } \\
\end{array}$ & $\begin{array}{l}\text { Patient engagement: } \\
\text { Completed activity } \\
\text { logs for } 2,3, \& 4 \\
\text { were } 36 \%, 1 \% \text {, and } \\
32 \% \text { resp. Patients } \\
\text { tried to enact } 1 \text { of } \\
\text { the goals set at prev } \\
\text { appt based on } \\
\text { discuss with mean } \\
\text { rating of } 3.41,3.01 \text {, } \\
\text { and } 3.80 . \\
\text { Patient } \\
\text { satisfaction/acceptab } \\
\text { ility: mean CSQ rating } \\
\text { was } 26.7 \text { out of } 35 \\
\text { indicating high level } \\
\text { of overall satisfaction } \\
\text { with number \& } \\
\text { duration of appts, } \\
\text { and in-person } \\
\text { format. Seven } \\
\text { patients cited ease of } \\
\text { access as main } \\
\text { reason for } \\
\text { satisfaction. } \\
\text { Reported high } \\
\text { likelihood of cont to } \\
\text { engage in activities } \\
\text { after study to } \\
\text { improve mood. } \\
\text { Treatment response: } \\
\text { within subjects t-test } \\
\text { revealed significant } \\
\text { reduction in } \\
\text { depressive symptoms }\end{array}$ & $\begin{array}{l}\text { Results of this } \\
\text { study support } \\
\text { feasibility, } \\
\text { acceptability, } \\
\text { and utility of } \\
\text { BA-PC. } \\
\text { Patients } \\
\text { reported high } \\
\text { levels of } \\
\text { satisfaction } \\
\text { with } \\
\text { intervention } \\
\text { overall, and } \\
\text { with specific } \\
\text { BA-PC } \\
\text { characteristic } \\
\text { s such as } \\
\text { length, } \\
\text { duration, and } \\
\text { format. } \\
\text { Patients } \\
\text { endorsed } \\
\text { high } \\
\text { likelihood of } \\
\text { continued } \\
\text { engagement, } \\
\text { indicating } \\
\text { high levels of } \\
\text { acceptance. } \\
\text { Patients } \\
\text { perceived } \\
\text { improvement } \\
\text { in depressive } \\
\text { symptoms, } \\
\text { corroborated }\end{array}$ \\
\hline
\end{tabular}




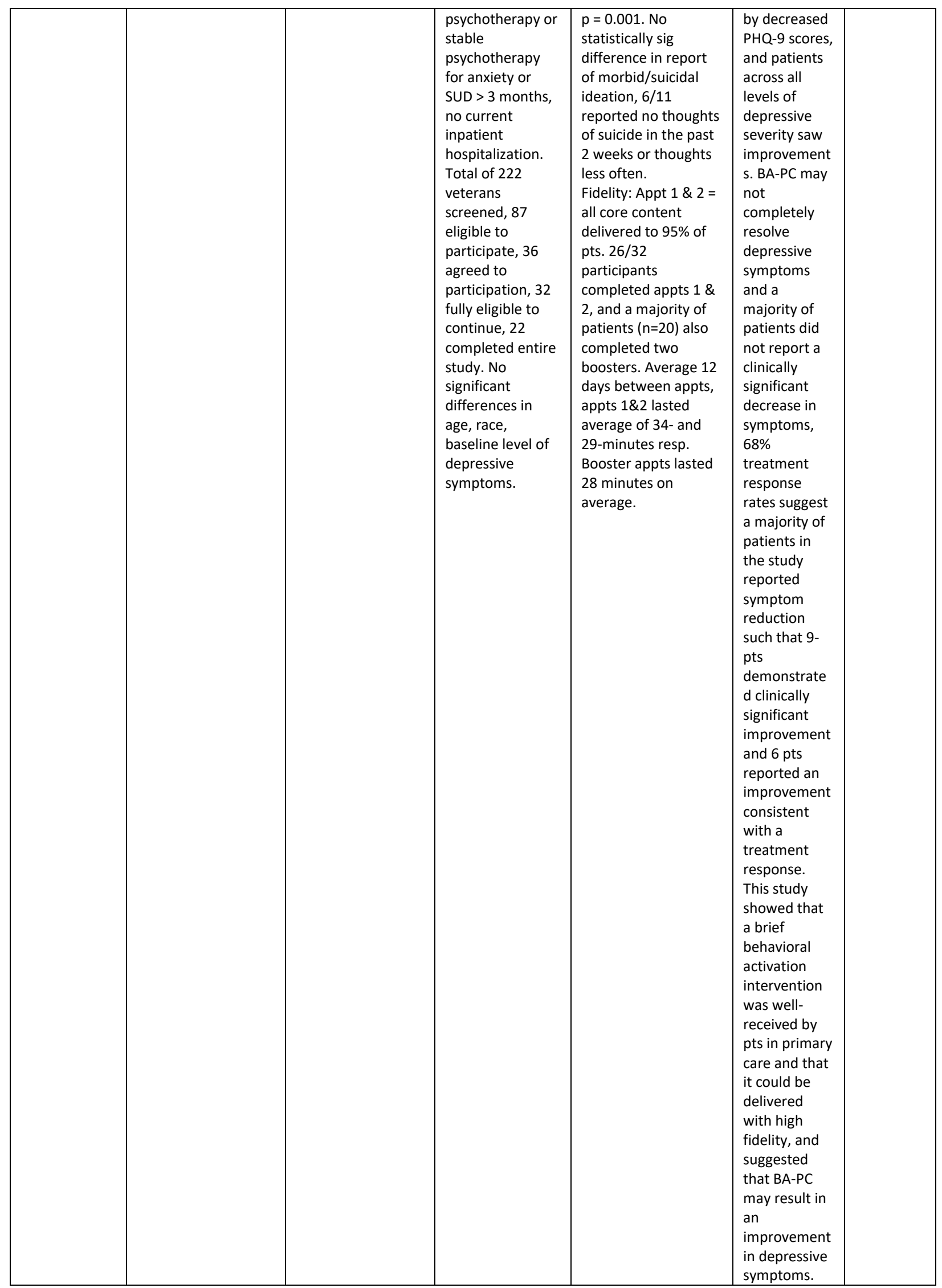




\begin{tabular}{|c|c|c|c|c|c|}
\hline $\begin{array}{l}\text { Gawrysiak, } \\
\text { M., Nicholas, } \\
\text { C., Hopko, } \\
\text { D.R. (2009). }\end{array}$ & $\begin{array}{l}\text { To use an RCT to } \\
\text { assess the efficacy of } \\
\text { single-session } \\
\text { individualized BA } \\
\text { intervention based } \\
\text { on the more } \\
\text { comprehensive BATD } \\
\text { protocol. }\end{array}$ & $\begin{array}{l}\text { RCT. Preliminary } \\
\text { power analysis } \\
\text { conducted. } \\
\text { Potential } \\
\text { participants were } \\
\text { recruited through } \\
\text { an online study } \\
\text { description and } \\
\text { websites } \\
\text { highlighting } \\
\text { counseling services } \\
\text { for students in } \\
\text { need. Participants } \\
\text { completed a BDI } \\
\text { and demographic } \\
\text { questionnaire for } \\
\text { eligibility. } \\
\text { Participants } 18 \\
\text { years and older } \\
\text { who scored } 14 \text { or } \\
\text { higher on the BDI } \\
\text { and were not } \\
\text { presently } \\
\text { undergoing } \\
\text { pharmacological or } \\
\text { psychological } \\
\text { treatment for } \\
\text { depression were } \\
\text { included, excluded } \\
\text { if involved with } \\
\text { psychotherapy } \\
\text { within the last } 2 \\
\text { years, active } \\
\text { suicidal intent, } \\
\text { current psychosis, } \\
\text { or bipolar disorder. } \\
\text { Treatment protocol } \\
\text { represented major } \\
\text { modification of } \\
\text { original BATD } \\
\text { intervention in that } \\
\text { it was reduced to a } \\
\text { one-session } \\
\text { treatment which } \\
\text { resulted in five } \\
\text { fewer weeks of } \\
\text { activity scheduling } \\
\text { making it a } \\
\text { nonprogressive } \\
\text { approach to } \\
\text { activating, in which } \\
\text { a greater number } \\
\text { of behaviors were } \\
\text { targeted for } \\
\text { activation } \\
\text { immediately, and } \\
\text { omission of } \\
\text { behavioral } \\
\text { contracting } \\
\text { for deprease rewsive } \\
\text { behaviors. } 90 \text {-min } \\
\text { individual } \\
\text { intervention } \\
\text { session by } 1 \text { of } 2 \\
\end{array}$ & $\begin{array}{l}\text { Introductory } \\
\text { psychology } \\
\text { students } \\
\text { recruited from a } \\
\text { public } \\
\text { Southeastern } \\
\text { university who } \\
\text { received credit } \\
\text { for participation. } \\
\text { All but } 2 \text { eligible } \\
\text { students agreed } \\
\text { to participate in } \\
\text { the study, and all } \\
\text { who participated } \\
\text { completed the } \\
\text { study. } 30 \\
\text { students overall, } \\
\text { BATD treatment } \\
\mathrm{n}=14 \text { and no } \\
\text { treatment } \mathrm{n}=16 . \\
\text { Recruitment } \\
\text { processes } \\
\text { involving self- } \\
\text { referral and } \\
\text { highlighting } \\
\text { aspirations for } \\
\text { depression } \\
\text { treatment as a } \\
\text { desired } \\
\text { participant } \\
\text { attribute }\end{array}$ & $\begin{array}{l}\text { Adherence to } \\
\text { treatment was } \\
\text { measured with the } \\
\text { weekly behavioral } \\
\text { checkout that was } \\
\text { returned to clinician } \\
\text { at post-treatment. All } \\
\text { outcome variables } \\
\text { were examined with } \\
\text { a } 2 \times 2 \text { repeated } \\
\text { measures analysis of } \\
\text { variance. Clinical } \\
\text { significance of pre- } \\
\text { post differences was } \\
\text { assessed using } \\
\text { Cohen's } d \text { statistic } \\
\text { where effect sizes of } \\
0.2,0.5, \text { and } 0.8 \text { are } \\
\text { considered small, } \\
\text { medium, and large. } \\
\text { Significant Group x } \\
\text { Time interactions } \\
\text { were evident on both } \\
\text { the BDI ( } p<0.01 \text { ) and } \\
\text { EROS ( }<<0.001 \text { ). } \\
\text { Large effect sizes on } \\
\text { both the BDI (1.61) } \\
\text { and EROS (1.14) } \\
\text { revealed clinically } \\
\text { significant } \\
\text { improvements. BAI } \\
\text { scores did not yield a } \\
\text { significant Group x } \\
\text { Time interaction ( } p= \\
0.25, d=0.36 \text { ). A } \\
\text { trend toward } \\
\text { increased social } \\
\text { support in BATD } \\
\text { group relative to } \\
\text { control condition at } \\
\text { post treatment ( } p= \\
0.08 \text { ) that was } \\
\text { characterized by a } \\
\text { moderate effect size } \\
\text { ( } d=0.70 \text { ). Reliable } \\
\text { change indices (RCI) } \\
\text { calculated for each } \\
\text { measure indicated } \\
\text { that on the BDI } 93 \% \\
\text { of individuals in the } \\
\text { BATD group } \\
\text { significantly } \\
\text { improved, compared } \\
\text { with only } 31 \% \text { in the } \\
\text { control group. On the } \\
\text { EROS, } 64 \% \text { of } \\
\text { individuals in the } \\
\text { BATD group } \\
\text { improved, where } 0 \% \\
\text { of participants in the } \\
\text { control group } \\
\text { demonstrated } \\
\text { clinically significant } \\
\text { change. MSPSS data } \\
\text { revealed that } 29 \% \text { of } \\
\text { individuals in the }\end{array}$ & $\begin{array}{l}\text { There was } \\
\text { strong } \\
\text { support for } \\
\text { the efficacy } \\
\text { of } 2 \text { weeks of } \\
\text { BA in } \\
\text { attenuating } \\
\text { symptoms of } \\
\text { depression } \\
\text { and } \\
\text { increasing } \\
\text { response- } \\
\text { contingent } \\
\text { positive } \\
\text { reinforcemen } \\
\text { t. There was } \\
\text { also } \\
\text { encouraging, } \\
\text { but not } \\
\text { statistically } \\
\text { significant, } \\
\text { evidence that } \\
\text { BATD might } \\
\text { show some } \\
\text { utility in } \\
\text { creating a } \\
\text { stronger and } \\
\text { more } \\
\text { rewarding } \\
\text { social support } \\
\text { system. } \\
\text { Change-score } \\
\text { data } \\
\text { supported a } \\
\text { strong } \\
\text { relationship } \\
\text { between } \\
\text { decreased } \\
\text { depression } \\
\text { and increased } \\
\text { RCPR, and } \\
\text { the good } \\
\text { compliance } \\
\text { rate in this } \\
\text { study } \\
\text { increases } \\
\text { confidence } \\
\text { that } \\
\text { improvement } \\
\text { was } \\
\text { associated } \\
\text { with BA and } \\
\text { increased } \\
\text { environment } \\
\text { al reward. An } \\
\text { important } \\
\text { consideration } \\
\text { of current } \\
\text { findings is } \\
\text { that pre-post } \\
\text { treatment } \\
\text { changes } \\
\text { resulted from } \\
\text { a single } 90- \\
\text { minute } \\
\text { session of } \\
\text { songion }\end{array}$ \\
\hline
\end{tabular}




\begin{tabular}{|c|c|c|c|c|}
\hline & . & $\begin{array}{l}\text { male doctoral } \\
\text { students in clinical } \\
\text { psych. Eligible } \\
\text { students were } \\
\text { contacted by } \\
\text { telephone and } \\
\text { asked to } \\
\text { participate. Within } \\
3 \text { days of } \\
\text { completing the } \\
\text { online depression } \\
\text { measure, } \\
\text { participants were } \\
\text { randomly assigned } \\
\text { to either the BATD } \\
\text { treatment or no- } \\
\text { treatment control } \\
\text { group. Each } \\
\text { participant then } \\
\text { had their initial } \\
\text { session in which } \\
\text { they were exposed } \\
\text { to either } 90 \text { min of } \\
\text { BATD or a general } \\
\text { discussion about } \\
\text { research } \\
\text { requirements and } \\
\text { their participation } \\
\text { in the study. } \\
\text { Follow-up sessions } \\
\text { were scheduled } 2 \\
\text { weeks later, during } \\
\text { which time } \\
\text { outcome measures } \\
\text { were administered, } \\
\text { behavioral } \\
\text { checkout form } \\
\text { returned, and } \\
\text { participants } \\
\text { debriefed. } \\
\text { Measures included } \\
\text { BDI (assesses the } \\
\text { severity of } \\
\text { depression } \\
\text { symptoms), EROS } \\
\text { (assesses } \\
\text { environmental } \\
\text { reward and RCPR, } \\
\text { or response } \\
\text { contingent positive } \\
\text { reinforcement with } \\
\text { higher scores } \\
\text { suggesting } \\
\text { increased } \\
\text { environmental } \\
\text { reward), BAI } \\
\text { (measures } \\
\text { cognitive and } \\
\text { somatic symptoms } \\
\text { of anxiety), and } \\
\text { MSPSS (assesses } \\
\text { the adequacy of } \\
\text { social support from } \\
\text { family and } \\
\text { significant others }\end{array}$ & $\begin{array}{l}\text { BATD group } \\
\text { improved } \\
\text { significantly } \\
\text { compared with only } \\
6 \% \text { in the control } \\
\text { group. } R C \text { analyses } \\
\text { of the BAI yielded } \\
\text { comparable findings } \\
\text { across groups with } \\
36 \% \text { of individuals in } \\
\text { the BATD group and } \\
31 \% \text { of participants in } \\
\text { the control group } \\
\text { demonstrated } \\
\text { clinically significant } \\
\text { change. Calculated } \\
\text { pre-post treatment } \\
\text { change scores to } \\
\text { determine the } \\
\text { degree to which } \\
\text { efforts to structure } \\
\text { guided activities and } \\
\text { engender } \\
\text { environmental } \\
\text { reward were } \\
\text { effective e in } \\
\text { reducing depressive } \\
\text { affect. Although } \\
\text { causality cannot be } \\
\text { inferred, change- } \\
\text { score data indicate } \\
\text { strong relationships, } \\
\text { whereby the } \\
\text { magnitude of } \\
\text { increased } \\
\text { environmental } \\
\text { reward was strongly } \\
\text { correlated with } \\
\text { decreased } \\
\text { depression ( } p<0.01 \text { ) } \\
\text { and anxiety ( } p< \\
0.05 \text { ), as well as } \\
\text { increased social } \\
\text { support ( } p<0.01 \text { ) }\end{array}$ & $\begin{array}{l}\text { BATD. } \\
\text { Although } \\
\text { follow-up } \\
\text { data were } \\
\text { not obtained, } \\
\text { results } \\
\text { suggest that } \\
\text { brief BA may } \\
\text { effectively } \\
\text { minimize } \\
\text { depressive } \\
\text { symptoms in } \\
\text { the short } \\
\text { term. In } \\
\text { summary, the } \\
\text { single-session } \\
\text { BATD } \\
\text { intervention } \\
\text { resulted in } \\
\text { significant } \\
\text { reductions in } \\
\text { depressive } \\
\text { symptoms } \\
\text { and increased } \\
\text { environment } \\
\text { al reward. } \\
\text { These } \\
\text { findings } \\
\text { suggest that } \\
\text { abbreviated } \\
\text { treatments } \\
\text { may have } \\
\text { some utility } \\
\text { toward } \\
\text { effectively } \\
\text { and } \\
\text { efficiently } \\
\text { reducing } \\
\text { depressive } \\
\text { symptoms in } \\
\text { moderately } \\
\text { depressed } \\
\text { university } \\
\text { students. }\end{array}$ \\
\hline
\end{tabular}




\begin{tabular}{|c|c|c|c|c|c|}
\hline & & $\begin{array}{l}\text { where higher } \\
\text { scores suggest } \\
\text { decreased social } \\
\text { support). }\end{array}$ & & & \\
\hline $\begin{array}{l}\text { Luoto, K.E., } \\
\text { Lindholm, } \\
\text { L.H., } \\
\text { Paavonen, V., } \\
\text { Koivukangas, } \\
\text { A., Lassila, A., } \\
\text { Leinonen, E., } \\
\text { \& Kampman, } \\
\text { O. (2018). }\end{array}$ & $\begin{array}{l}\text { To explore the } \\
\text { benefits of BA in a } \\
\text { heterogeneous } \\
\text { group of depressed } \\
\text { patients in a } \\
\text { naturalistic setting } \\
\text { and to compare BA } \\
\text { with treatment as } \\
\text { usual in terms of } \\
\text { functional recovery, } \\
\text { service use, dropout, } \\
\text { and mortality. }\end{array}$ & 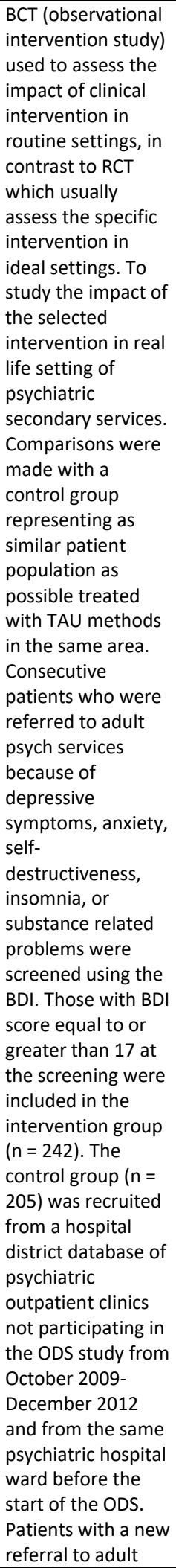 & $\begin{array}{l}\text { Recruited from } \\
\text { five psychiatric } \\
\text { outpatient clinics } \\
\text { and one } \\
\text { psychiatric } \\
\text { hospital ward } \\
\text { (Finland) during } \\
\text { October 2009- } \\
2013 .\end{array}$ & $\begin{array}{l}\text { Improvement of } \\
\text { depressive symptoms } \\
\text { in intervention } \\
\text { patients was } \\
\text { analyzed using } \\
\text { MADRS scores. Mean } \\
\text { score for intervention } \\
\text { patients at baseline } \\
\text { was } 23.2 \text { pts, } 13.1 \text { at } \\
6 \text { months, } 9.93 \text { at } 12 \\
\text { months, and } 8.31 \text { at } \\
24 \text { months. Change in } \\
\text { MADRS was } \\
\text { statistically } \\
\text { significant in every } \\
\text { follow-up period. At } \\
12-\text { and } 24-\text { months } \\
\text { follow-up the } \\
\text { estimated } \\
\text { improvement in GAF } \\
\text { score was } \\
\text { significantly better in } \\
\text { the intervention } \\
\text { group ( } p=0.036 \text { ). At } \\
\text { six months a similar } \\
\text { difference was not } \\
\text { found. Sensitivity } \\
\text { analysis was } \\
\text { performed by } \\
\text { excluding patients } \\
\text { with personality } \\
\text { disorder as } \\
\text { secondary clinical } \\
\text { diagnosis ( } n=44 \text { ). } \\
\text { Results were similar } \\
\text { with the total sample } \\
\text { analysis with GAF } \\
\text { estimates between } \\
\text { intervention and } \\
\text { control groups at } 6 \\
\text { months ( } p=0.057 \text { ), } \\
12 \text { months ( } p= \\
0.006 \text { ), and } 24 \\
\text { months ( } p=0.002 \text { ). } \\
\text { There was no } \\
\text { between-group } \\
\text { differences in } \\
\text { number of outpatient } \\
\text { visits during any } \\
\text { follow-up period. } \\
\text { Need for } \\
\text { hospitalization was } \\
\text { measured in every } \\
\text { follow-up period and } \\
\text { number of } \\
\text { hospitalized patients } \\
\text { was similar in the } \\
\text { intervention and } \\
\text { control groups during } \\
\text { all periods. Among } \\
\text { patients who were } \\
\text { hospitalized at }\end{array}$ & $\begin{array}{l}\text { Since only } \\
\text { patients with } \\
\text { psychotic or } \\
\text { organic } \\
\text { pathologies } \\
\text { were } \\
\text { excluded this } \\
\text { study was } \\
\text { heterogeneo } \\
\text { us with } \\
\text { various } \\
\text { comorbidities } \\
\text { and therefore } \\
\text { representativ } \\
\text { e of the usual } \\
\text { patient } \\
\text { population in } \\
\text { everyday } \\
\text { practice. } \\
\text { Depressive } \\
\text { symptoms } \\
\text { among the } \\
\text { intervention } \\
\text { group } \\
\text { patients } \\
\text { seemed to } \\
\text { alleviate } \\
\text { compared to } \\
\text { baseline } \\
\text { during the } 2 \\
\text { years of } \\
\text { follow-up. } \\
\text { Results } \\
\text { suggest that } \\
\text { BA is a useful } \\
\text { tool although } \\
\text { strong } \\
\text { conclusions } \\
\text { can't be } \\
\text { drawn about } \\
\text { the benefits } \\
\text { compared to } \\
\text { TAU. } \\
\text { Intervention } \\
\text { patients } \\
\text { showed a } \\
\text { greater } \\
\text { improvement } \\
\text { in functional } \\
\text { ability than } \\
\text { control. } \\
\text { Functional } \\
\text { recovery has } \\
\text { a } \\
\text { considerable } \\
\text { effect on } \\
\text { daily life and } \\
\text { is particularly } \\
\text { relevant from } \\
\text { patients' } \\
\text { point of view. } \\
\text { Intervention }\end{array}$ \\
\hline
\end{tabular}




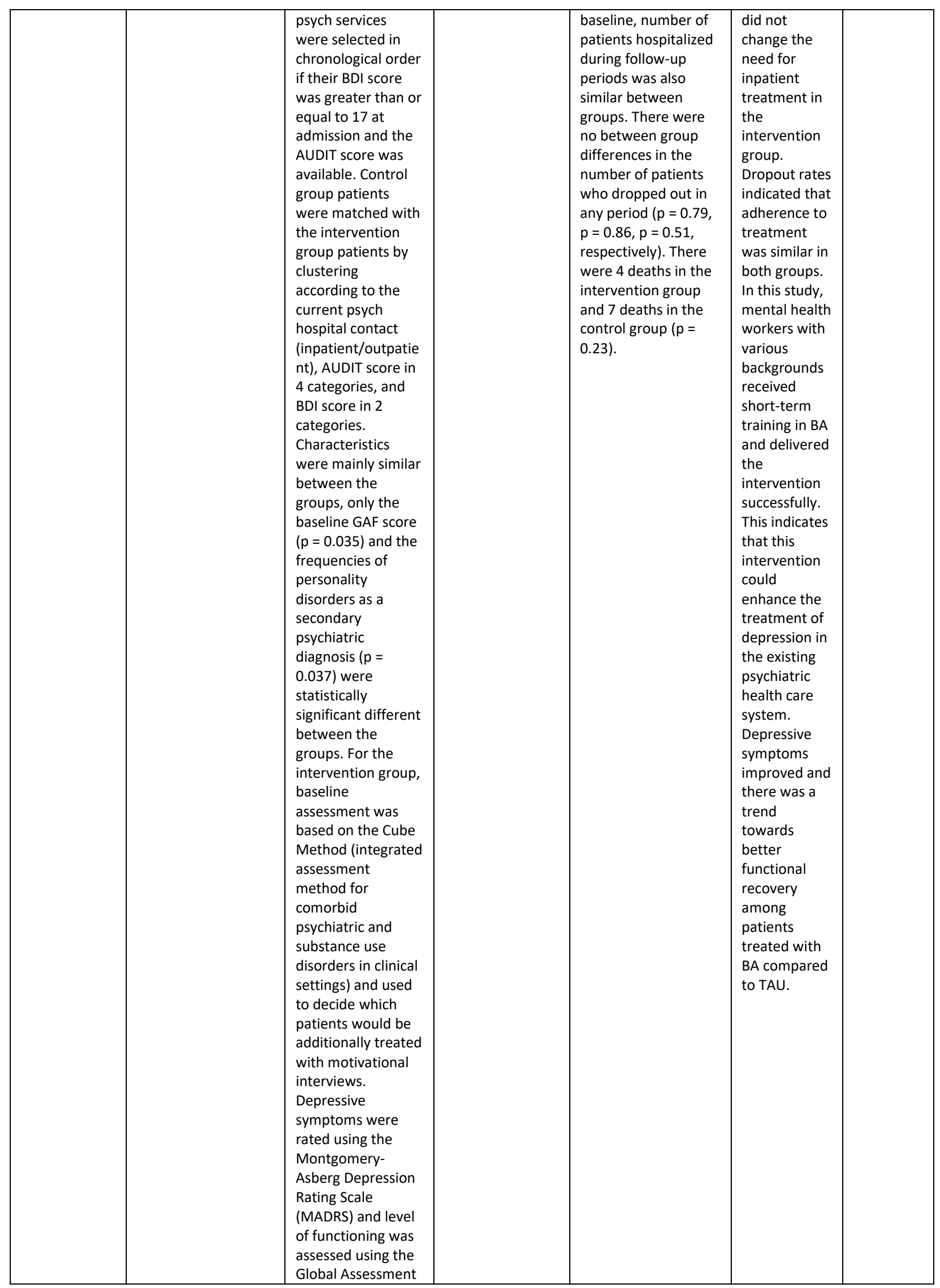




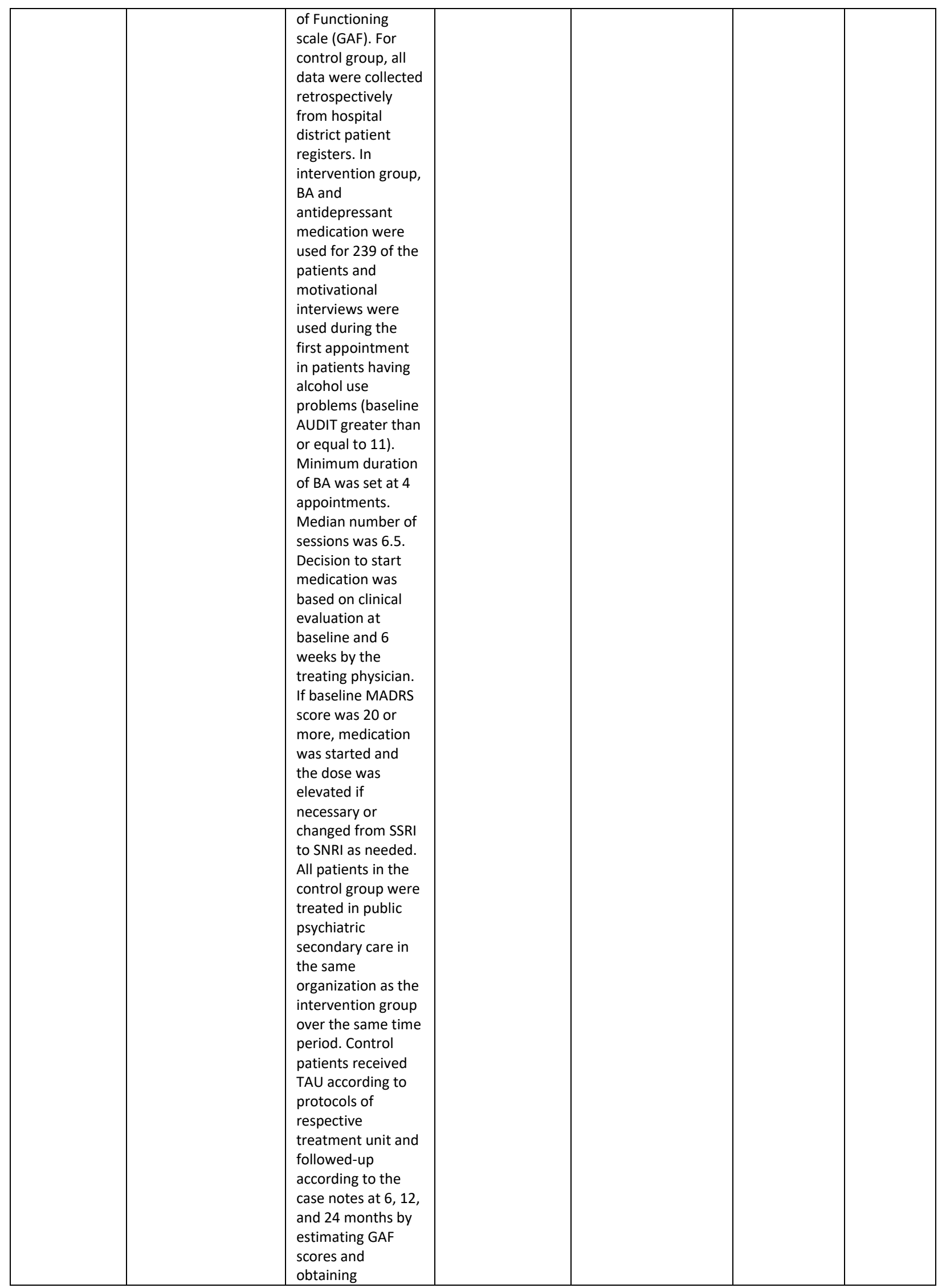




\begin{tabular}{|c|c|c|c|c|}
\hline & & $\begin{array}{l}\text { information about } \\
\text { possible alcohol } \\
\text { use. For both } \\
\text { groups, info about } \\
\text { frequency of visits, } \\
\text { number of hospital } \\
\text { days, and dropouts } \\
\text { were collected } \\
\text { from patient } \\
\text { registers at } 6,12 \text {, } \\
\text { and } 24 \text { months } \\
\text { follow-up. }\end{array}$ & & \\
\hline $\begin{array}{l}\text { Mazzucchelli, } \\
\text { T., Kane, R., \& } \\
\text { Rees, C. } \\
\text { (2009). }\end{array}$ & $\begin{array}{l}\text { To identify all } \\
\text { randomized } \\
\text { controlled studies of } \\
\text { BA, to determine the } \\
\text { effect of this } \\
\text { approach, and to } \\
\text { examine the } \\
\text { differential } \\
\text { effectiveness of } \\
\text { variants. } \\
\text { Interventions } \\
\text { included pleasant } \\
\text { activities, self- } \\
\text { control, contextual } \\
\text { behavioral } \\
\text { activation, and } \\
\text { BATD. }\end{array}$ & $\begin{array}{l}\text { Meta-analysis. } \\
\text { Searched PsycINFO } \\
\text { and MEDLINE } \\
\text { databases for } \\
\text { articles published } \\
\text { between January } \\
1970 \text { and } \\
\text { September } 2008 \\
\text { that included the } \\
\text { terms activity } \\
\text { scheduling, } \\
\text { behavioral/behavio } \\
\text { ural activation, } \\
\text { pleasant events, or } \\
\text { pleasant activities. } \\
\text { Studies were } \\
\text { included if effects } \\
\text { of BA on typically } \\
\text { developing adults } \\
\text { with depressive } \\
\text { disorder or } \\
\text { elevated levels of } \\
\text { depressive } \\
\text { symptomology } \\
\text { were compared } \\
\text { with a control } \\
\text { condition or } \\
\text { another } \\
\text { psychological or } \\
\text { active } \\
\text { pharmacological } \\
\text { treatment in a RCT. }\end{array}$ & $\begin{array}{l}\text { BA vs. Control } \\
\text { conditions - The } \\
\text { effect of BA against } \\
\text { control was large } \\
\text { with a pooled effect } \\
\text { size of } 0.78 \\
\text { demonstrating a } \\
\text { highly significant } \\
\text { difference favoring } \\
\text { BA. BA vs. Other } \\
\text { conditions - } \\
\text { Negligible pooled } \\
\text { effect size of -0.01 } \\
\text { between treatments } \\
\text { was nonsignificant. } \\
\text { Subgroup analyses } \\
\text { indicated that the } \\
\text { pleasant activities } \\
\text { variant of BA yielded } \\
\text { a small effect in favor } \\
\text { of CBT/CT, self- } \\
\text { control variant } \\
\text { yielded negligible } \\
\text { effect in favor of } \\
\text { CBT/CT, and } \\
\text { contextual variant } \\
\text { yielded small effect } \\
\text { in favor of BA. Effect } \\
\text { sizes of different } \\
\text { variants of BA were } \\
\text { not found to differ } \\
\text { significantly from } \\
\text { each other. Effects at } \\
\text { follow-up - BA vs. } \\
\text { control at } 1-3 \text { month } \\
\text { follow-up was large } \\
\text { with pooled effect of } \\
0.78, \text { demonstrating } \\
\text { highly significant } \\
\text { difference favoring } \\
\text { BA; at 7-12 month } \\
\text { follow-up effect was } \\
\text { small at } 0.08 \text { and } \\
\text { nonsignificant in } \\
\text { favor of BA. BA vs. } \\
\text { CBT/CT at } 1-3,4-6,7- \\
12, \text { and } 13-24 \\
\text { months effect size } \\
\text { was small and } \\
\text { nonsignificant with } \\
\text { an effect size ranging } \\
\text { from - } 0.10 \text { in favor of } \\
\text { CBT/CT to 0.05 in } \\
\text { favor of BA. BA vs. }\end{array}$ & $\begin{array}{l}\text { Results } \\
\text { indicate that } \\
\text { BA is } \\
\text { effective in } \\
\text { the } \\
\text { treatment of } \\
\text { depression. } \\
\text { Individuals } \\
\text { with elevated } \\
\text { scores on } \\
\text { self-report } \\
\text { depression } \\
\text { measures, } \\
\text { overall effect } \\
\text { size in favor } \\
\text { of BA over } \\
\text { control is } \\
\text { large and } \\
\text { comparable } \\
\text { with the } \\
\text { effect size } \\
\text { found by } \\
\text { previous } \\
\text { meta- } \\
\text { analyses. } \\
\text { Patients } \\
\text { meeting } \\
\text { diagnostic } \\
\text { criteria for } \\
\text { MDD, overall } \\
\text { effect size } \\
\text { remained } \\
\text { large and } \\
\text { significant. } \\
\text { Comparisons } \\
\text { of BA with CT } \\
\text { of CBT } \\
\text { indicated that } \\
\text { these } \\
\text { treatments } \\
\text { were equally } \\
\text { effective. } \\
\text { There is } \\
\text { evidence that } \\
\text { BA has } \\
\text { equivalent } \\
\text { effects to } \\
\text { CBT/CT for up } \\
\text { to } 24 \text { months. } \\
\text { Although } \\
\text { more recent } \\
\text { variants of } \\
\text { BA, such as } \\
\text { contextual }\end{array}$ \\
\hline
\end{tabular}




\begin{tabular}{|c|c|c|c|c|c|}
\hline & & & & $\begin{array}{l}\text { psychotherapy or } \\
\text { other treatments at } \\
1-3 \text { months showed } \\
\text { pooled effect size of } \\
0.23 \text { indicating a } \\
\text { small, nonsignificant } \\
\text { difference in favor of } \\
\text { BA; BA vs. } \\
\text { psychotherapy only } \\
\text { at } 4-6 \text { and } 7-12 \\
\text { months effect sizes } \\
\text { were large but } \\
\text { nonsignificant in } \\
\text { favor of BA. }\end{array}$ & $\begin{array}{l}\text { BA, showed } \\
\text { greater } \\
\text { effects than } \\
\text { earlier } \\
\text { variants, all } \\
\text { produced } \\
\text { effects of } \\
\text { similar } \\
\text { magnitude } \\
\text { and } \\
\text { differences } \\
\text { between } \\
\text { them were } \\
\text { not } \\
\text { significant. } \\
\text { Focused } \\
\text { evidence } \\
\text { review } \\
\text { indicated that } \\
\text { contextual BA } \\
\text { has the } \\
\text { strongest } \\
\text { evidence } \\
\text { base and } \\
\text { satisfies the } \\
\text { APA's } \\
\text { Division } 12 \\
\text { Task Force's } \\
\text { probably } \\
\text { efficacious } \\
\text { designation } \\
\text { for the } \\
\text { treatment of } \\
\text { MDD, and } \\
\text { could be } \\
\text { argued that } \\
\text { the BA } \\
\text { approach in } \\
\text { general } \\
\text { satisfies the } \\
\text { well- } \\
\text { established } \\
\text { designation. } \\
\end{array}$ \\
\hline $\begin{array}{l}\text { Richards, D.A., } \\
\text { Ekers, D., } \\
\text { McMillan, D., } \\
\text { Taylor, R.S., } \\
\text { Byford, S., } \\
\text { Warren, F.C., } \\
\text { Barrett, B., } \\
\text { Farrand, P.A., } \\
\text { Gilbody, S., } \\
\text { Kuyken, W., } \\
\text { O'Mahen, H., } \\
\text { Watkins, E.R., } \\
\text { Wright, K.A., } \\
\text { Hollon, S.D., } \\
\text { Reed, N., } \\
\text { Rhodes, S., } \\
\text { Fletcher, E., \& } \\
\text { Finning, K. } \\
\text { (2016). }\end{array}$ & $\begin{array}{l}\text { To establish clinical } \\
\text { efficacy and cost- } \\
\text { effectiveness of BA } \\
\text { compared with CBT } \\
\text { for adults with } \\
\text { depression. }\end{array}$ & $\begin{array}{l}\text { Randomized, } \\
\text { controlled, open- } \\
\text { label, non- } \\
\text { inferiority trial. } \\
\text { Patients were } \\
\text { recruited using } \\
\text { patient records of } \\
\text { general practices } \\
\text { and psychological } \\
\text { therapy services for } \\
\text { patients with } \\
\text { depression, } \\
\text { identified by } \\
\text { depression codes. } \\
\text { Practices/services } \\
\text { contacted patients } \\
\text { to seek permission } \\
\text { for researcher } \\
\text { contact, research } \\
\text { team interviewed } \\
\text { those that } \\
\text { responded and } \\
\text { assessed for }\end{array}$ & $\begin{array}{l}\text { Recruited from } \\
\text { primary care and } \\
\text { psychological } \\
\text { therapy services } \\
\text { in Devon, } \\
\text { Durham, and } \\
\text { Leeds. Eligible } \\
\text { participants were } \\
\text { adults } 18 \text { years } \\
\text { and older who } \\
\text { met diagnostic } \\
\text { criteria for MDD } \\
\text { according to } \\
\text { standard clinical } \\
\text { interview. } \\
\text { Exclusion criteria } \\
\text { were patients } \\
\text { receiving } \\
\text { psychological } \\
\text { therapy, alcohol } \\
\text { or drug } \\
\text { dependence, } \\
\text { acute suicidal or }\end{array}$ & $\begin{array}{l}\text { Between Sept 26, } \\
2012 \text { and April 3, } \\
2014 \text { authors } \\
\text { recruited } 440 \\
\text { participants, } \\
\text { randomizing } 221 \\
\text { participants to the BA } \\
\text { group and } 219 \text { to the } \\
\text { CBT group. } \\
\text { Participants received } \\
\text { an average of } 11.5 \text { BA } \\
\text { sessions or } 12.5 \text { CBT } \\
\text { sessions. Found no } \\
\text { evidence of } \\
\text { inferiority between } \\
\text { mITT or PP } \\
\text { populations. Found } \\
\text { no evidence of a } \\
\text { significant between- } \\
\text { group treatment } \\
\text { interaction across the } \\
\text { mITT or PP group } \\
\text { with primary }\end{array}$ & $\begin{array}{l}\text { BA for } \\
\text { depression is } \\
\text { not inferior } \\
\text { to CBT in } \\
\text { terms of } \\
\text { reduction of } \\
\text { depressive } \\
\text { symptoms } \\
\text { and is more } \\
\text { cost-effective } \\
\text { than is CBT. } \\
\text { Economic } \\
\text { analyses } \\
\text { were driven } \\
\text { by lower } \\
\text { costs of } \\
\text { MHWs who } \\
\text { delivered BA } \\
\text { compared } \\
\text { with more } \\
\text { experienced } \\
\text { psychological } \\
\text { therapists }\end{array}$ \\
\hline
\end{tabular}




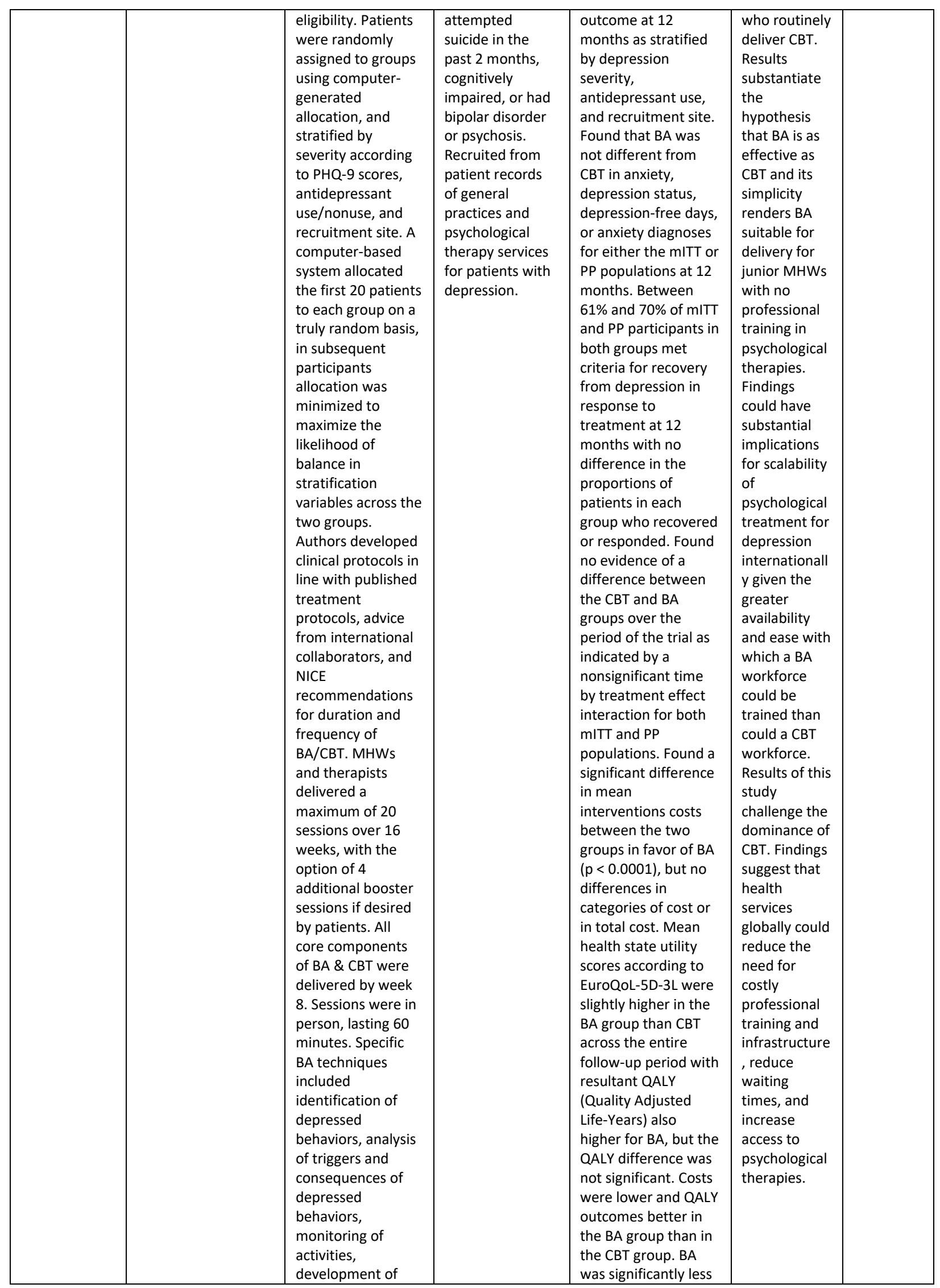




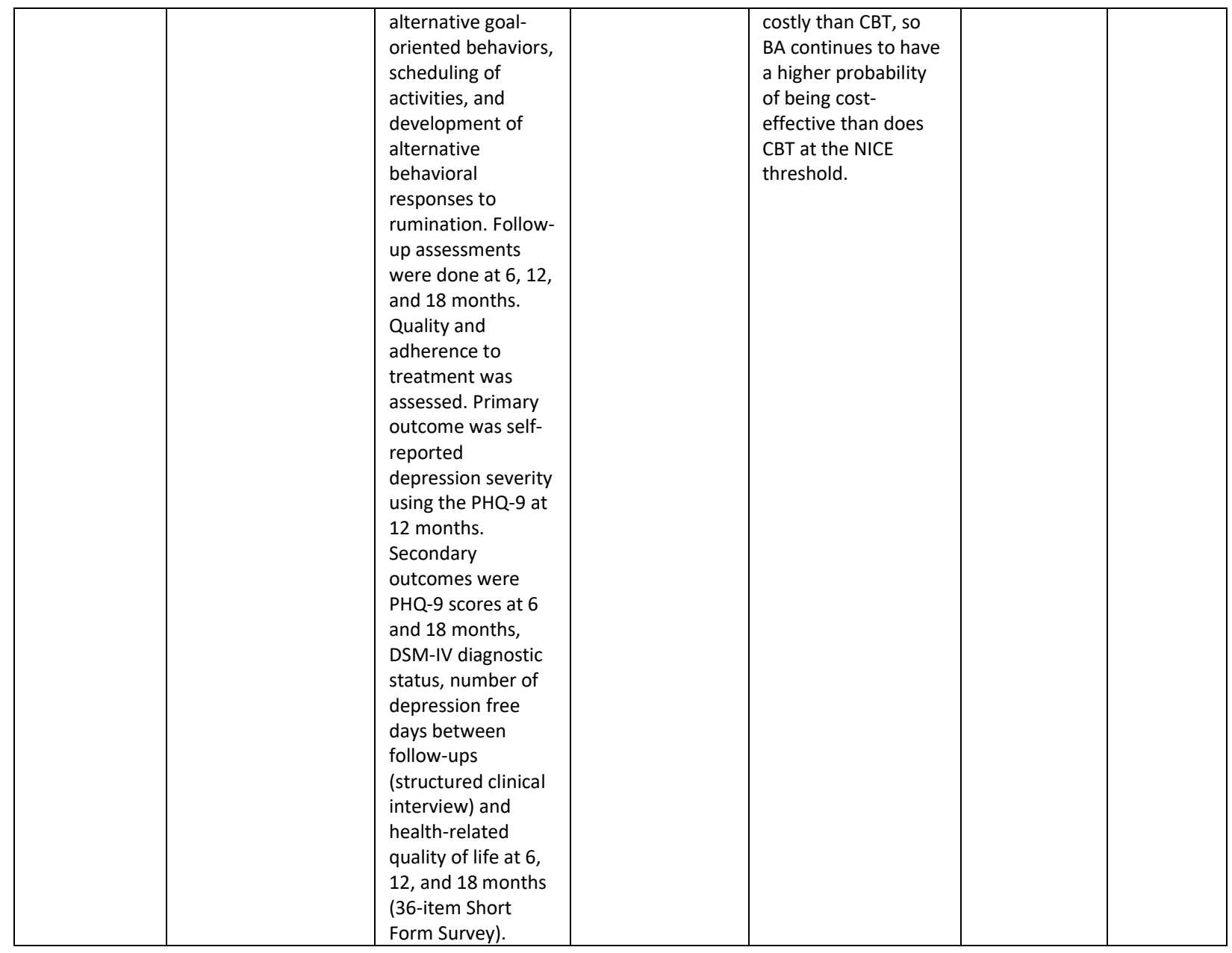


Appendix B

Form 1. Daily Monitoring

\begin{tabular}{|c|c|c|c|}
\hline Time & Activity & $\begin{array}{c}\text { Enjoyment } \\
(\mathbf{0}-10)\end{array}$ & $\begin{array}{c}\text { Importance } \\
(\mathbf{0}-10)\end{array}$ \\
\hline $5-6 \mathrm{am}$ & & & \\
\hline $6-7 \mathrm{am}$ & & & \\
\hline $7-8 \mathrm{am}$ & & & \\
\hline $8-9 \mathrm{am}$ & & & \\
\hline $9-10 \mathrm{am}$ & & & \\
\hline $10-11 \mathrm{am}$ & & & \\
\hline $11-12 \mathrm{am}$ & & & \\
\hline $12-1 \mathrm{pm}$ & & & \\
\hline $1-2 \mathrm{pm}$ & & & \\
\hline $2-3 \mathrm{pm}$ & & & \\
\hline $3-4 \mathrm{pm}$ & & & \\
\hline $4-5 \mathrm{pm}$ & & & \\
\hline $5-6 \mathrm{pm}$ & & & \\
\hline $6-7 \mathrm{pm}$ & & & \\
\hline $7-8 \mathrm{pm}$ & & & \\
\hline $8-9 \mathrm{pm}$ & & & \\
\hline $9-10 \mathrm{pm}$ & & & \\
\hline $10-11 \mathrm{pm}$ & & & \\
\hline $11-12 \mathrm{pm}$ & & & \\
\hline $12-1 \mathrm{am}$ & & & \\
\hline $1-2 \mathrm{am}$ & & & \\
\hline $2 \rightarrow 5 \mathrm{am}$ & & & \\
\hline
\end{tabular}




\section{Appendix C}

Form 2. Life Areas, Values, and Activities Inventory

Life Area (1/5): Relationships

\begin{tabular}{|c|c|c|}
\hline Value: & $\begin{array}{c}\text { Enjoyme } \\
\text { nt (0-10) }\end{array}$ & $\begin{array}{c}\text { Importan } \\
\text { ce (0-10) }\end{array}$ \\
\hline - Activity 1: & & \\
\hline - Activity 2: & & \\
\hline - Activity 3: & & \\
\hline Activity 4: & & \\
\hline - Activity 5: & & \\
\hline
\end{tabular}

\begin{tabular}{|c|c|c|}
\hline Value: & $\begin{array}{c}\text { Enjoyme } \\
\text { nt (0-10) }\end{array}$ & $\begin{array}{c}\text { Importan } \\
\text { ce (0-10) }\end{array}$ \\
\hline - Activity 1: & & \\
\hline - Activity 2: & & \\
\hline - Activity 3: & & \\
\hline - Activity 4: & & \\
\hline
\end{tabular}

\begin{tabular}{|c|c|c|}
\hline Value: & $\begin{array}{c}\text { Enjoyme } \\
\text { nt (0-10) }\end{array}$ & $\begin{array}{c}\text { Importan } \\
\text { ce (0-10) }\end{array}$ \\
\hline - Activity 1: & & \\
\hline - Activity 2: & & \\
\hline - Activity 3: & & \\
\hline - Activity 4: & & \\
\hline - Activity 5: & & \\
\hline
\end{tabular}




\section{Appendix D}

Form 3. Activity Selection and Ranking

Instructions: List your desired 15 activities and rate the difficulty of each from $1=$ least difficult to $15=$ most difficult.

\begin{tabular}{|l|l|}
\hline ACTIVTY & RANK \\
\hline & \\
\hline & \\
\hline & \\
\hline & \\
\hline & \\
\hline & \\
\hline & \\
\hline & \\
\hline & \\
\hline & \\
\hline & \\
\hline & \\
\hline & \\
\hline
\end{tabular}




\section{Appendix E}

\section{Form 4. Contracts}

What is an activity you could use help to complete?

Name one person who can help you with this activity:

What are the ways this person can help you with this activity:

1.

$-$

2.

3.

Name one person who can help you with this activity:

What are the ways this person can help you with this activity:

1.

$-$

3. 
Appendix F

\begin{tabular}{|c|c|c|c|c|c|c|}
\hline Patient & $\begin{array}{c}\text { PHQ- } \\
9 \text { Pre }\end{array}$ & $\begin{array}{c}\text { BADS } \\
\text { Pre }\end{array}$ & $\begin{array}{c}\text { PHQ-9 } \\
\text { Post }\end{array}$ & $\begin{array}{c}\text { BADS } \\
\text { Post }\end{array}$ & $\begin{array}{c}\text { Change } \\
\text { in PHQ- } \\
9\end{array}$ & $\begin{array}{c}\text { Change } \\
\text { in } \\
\text { BADS }\end{array}$ \\
\hline 1 & 19 & 17 & 9 & 35 & -10 & +18 \\
\hline 2 & 12 & 21 & N/A & N/A & N/A & N/A \\
\hline 3 & 14 & 14 & 15 & N/A & +1 & N/A \\
\hline 4 & 16 & 24 & N/A & N/A & N/A & N/A \\
\hline Average & 15.25 & 19 & 12 & N/A & & \\
\hline
\end{tabular}

\section{Appendix G}

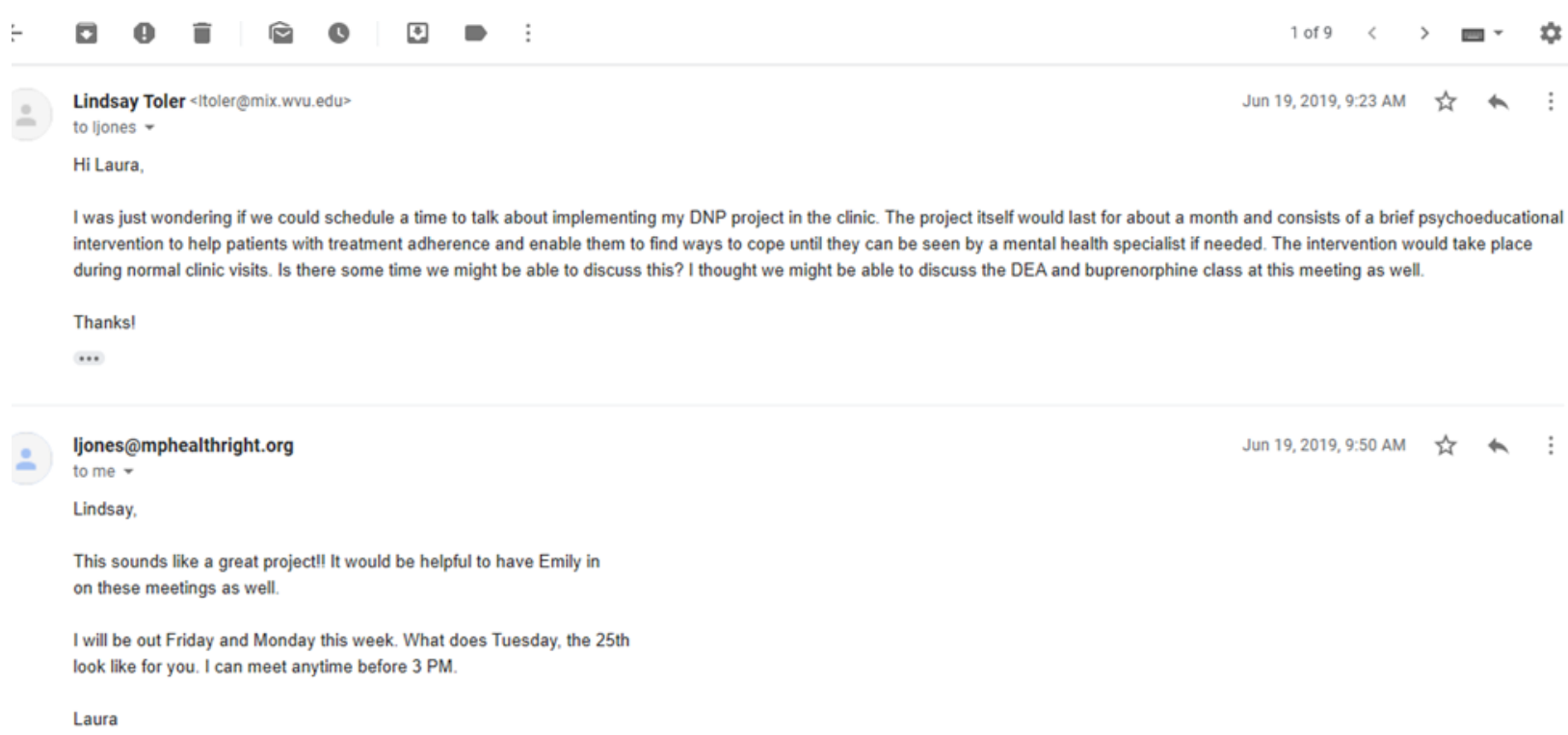


Appendix H

1-Dec-19 20-Jan-20 10-Mar-20 29-Apr-20 18-Jun-20 7-Aug-20 26-Sep-20 15-Nov-20 4-Jan-21

Project Proposal Committee Approval Clinic Approval IRB Submission/Approval Prepare Materials Staff Education Write Manuscript Identify Patients Implement Intervention Data Collection Analyze Data Clinic Debriefing Evaluate Goals/Object Finalize Manuscript Final Draft to Committee Defend Submit
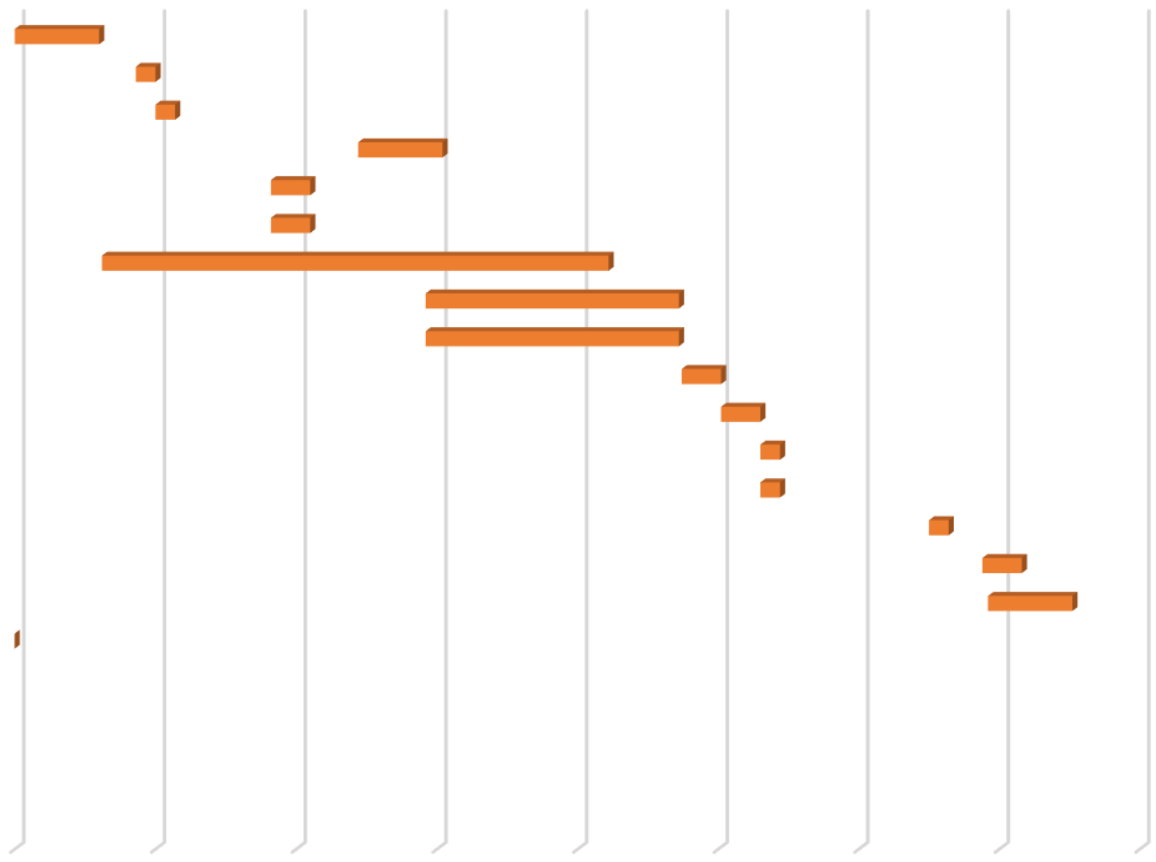